\title{
Kentsel Ulaşımda Özel Araç Odaklı Düzenlemelere Eleştirel Bir Bakış
}

\author{
DOI: $10.26466 /$ opus.607571
}

\begin{abstract}
$*$
\section{Aysu Uğurlar*}

* Dr. Öğr. Üyesi Van Yüzüncü Yıl Üniversitesi Mimarlık ve Tasarım Fakültesi , Tuşpa/Van/Türkiye E-Posta: augurlar@yyu.edu.tr

ORCID: $\underline{0000-0001-6172-7906}$

\section{Öz}

Özellikle 1980'li yıllarda çevre bilincinin artması ve var olan kaynakların azalması gibi nedenler sinırlı bir ortam içinde sınırsız bir gelişmenin olamayacağı farkındalı̆̆ını oluşturmuştur. Bu bağlamda ortaya çıkan "sürdürülebilir gelişme" kavramı birçok alanda olduğu gibi ulaşım politikalarında da kendini göstermiştir. Genel olarak "sürdürülebilir bir ulaşım" insan ve ekosistem sağhlğını, ekonomik gelişmeyi ve sosyal adaleti koruyup geliştirmek koşulu ile hem günümüz hem gelecek için hareketlilik ihtiyacının karşılanması olarak tanımlanmaktadır. Sürdürülebilir kent içi ulaşım kavramı ise temelde toplumun tüm bireylerine eşit erişim imkânı sunan, toplu taşımayı ve motorsuz ulaşım alternatiflerini ön planda tutan, diğer ulaşım türleri(modları) ile entegrasyonunu sağlayan kapsaml bir ulaşım sistemidir. Günümüzde hem gelişmiş hem de Türkiye gibi gelişmekte olan ülkelerde sürdürülebilir ulaşım sistemleri oluşturulması hususunda çabalar gösterilmekte ve çeşitli politikalar uygulanmaktadır. Bu çalışmada, Van kent merkezi iş alanında (MİA) ilgili yerel yönetimin ilgili birimi olan Ulaşım ve Koordinasyon Merkezi tarafindan mevcut trafik yoğunluğunu azaltmak amacı ile parkomat uygulaması ve kent merkezinin iki ana caddelerinden biri olan Cumhuriyet Caddesi'nin bir kısmının toplu taşım güzergâhı kapsamından çıkarılması ele alınmaktadır. Buradan hareketle çalışmada, yerel yönetimin bu düzenlemeleri sürdürülebilir ulaşım politikaları bă̆lamında mevzuat ve mekânsal açısından tartışılmaktadır.
\end{abstract}

Anahtar Kelimeler: Sürdürülebilir Kentsel Ulaşım, Toplu Taşıma, Yerel Yönetim, Düzenlemeler, Van. 


\title{
A Critical Perspective on Private Vehicle Oriented Regulations in Urban Transport
}

\begin{abstract}
Especially in the 1980s, the increase in environmental awareness and the decrease of existing resources have created the consciousness that unlimited development cannot be possible in a limited environment. The concept of sustainable development emerged in this context has been reflected in transportation policies, as in many other areas. In general, sustainable transportation is defined as meeting the mobility needs for both present and future with the condition of protecting and developing human and ecosystem health, economic development, and social justice. The concept of sustainable urban transportation refers basically to a comprehensive transportation system that provides equal access to all individuals of the society and fosters integration of public transportation and non-motorized transportation alternatives with other types (modes) of transportation. Today, both in developed countries and developing countries such as Turkey, efforts are spent to establish sustainable transport systems and various policies are implemented to this end. The present study examines the parking meter and exclusion of a part of Cumhuriyet Street, which is one of the two main streets of Van central business district (CBD) from public transportation route by the Transportation and the Coordination Center department of the local government in order to reduce the current traffic density. From this perspective, the implementation and policy of the local government's change of route are discussed both in terms of sustainable transport policies and legislation.
\end{abstract}

Keywords: Sustainable Urban Transport, Public Transport, Local Government, Regulations, Van 


\section{Giriş}

Özellikle 1980'li yıllarda mevcut kaynakların azalması, çevre bilincinin artması gibi nedenlere bağlı olarak sınırlı bir ortam içinde sınırsız bir gelişmenin olamayacağ 1 farkındalığı oluşmuş ve sürdürülebilirlik kavramı yaygınlaşmaya başlamıştır (Acar, 2003, s.44; Yiğitcanlar, Fabian ve Coiacetto, 2008, s.30). Küreselleşme süreci ile birlikte sürdürülebilir gelişme temel olarak gelecek nesillerin ihtiyaçlarına zarar vermeksizin bugünkü nesillerin ihtiyacını karşılamaktır. Bu bağlamda ortaya çıkan sürdürülebilir gelişme kavramı ulaşım politikalarında da kendini göstermeye başlamıştır (Acar, 2003, s.44). Son yıllarda çevre ve sağlık sorunlarının artması ise sürdürülebilir kentsel ulaşım literatüründe önemli araştırmalara neden olmuştur. Bu araştırmalar; kentsel ulaşımın uzun vadeli çevresel etkisine ilişkin araç emisyonlarından kaynaklanan kentsel hava kirliliğine, küresel iklim değişikliğine, enerji kaynaklarının aşırı tüketilmesine, doğal ortamların tahrip edilmesine ve gürültü kirliliğine kadar çeşitlenmektedir (Boschmann ve Kwan, 2008, s.139).

Ulaşım; sürdürülebilir ulaşımın sosyal, ekonomik ve çevresel boyutları dengelendiğinde; daha iyi bir yaşam için bireylerin ihtiyaçlarının ve isteklerinin karşılanmasını sağlamada önemli bir mekanizmadır (Boschmann ve Kwan, 2008, s.139). Sürdürülebilir bir ulaşım genel olarak "günümüz ve gelecek için insan ve ekosistem sağlığını, ekonomik gelişmeyi ve sosyal adaleti koruyup geliştirmek koşuluyla hareketlilik gereksiniminin karşılanması" olarak tanımlanmaktadır (Deakin, 2001:5-6 alıntılayan Cirit, 2014, s.10). Buradan hareketle sürdürülebilir kentsel ulaşımda sadece çevresel ve ekonomik değil sosyal boyutun da öne çıtığı görülmektedir. Sosyal açıdan sürdürülebilir kentsel ulaşım, literatürde sosyal eşitlik, sosyal dışlanma ve yaşam kalitesi unsurları ile ifade edilmektedir. Diğer ifade ile sosyal olarak sürdürülebilir bir kentsel ulaşım kentsel fırsatlara erişimi sağlar, sosyal dişlanmayı en aza indirir ve bireyin yaşam kalitesini artırır (Boschmann ve Kwan, 2008, s.140). Sürdürülebilir kent planlama, kentsel form, yer seçimi ve birey odaklı erişebilirlik gibi bazı araştırma alanları teorik, metodolojik açılardan sosyal olarak sürdürülebilir kentsel ulaşım çalışmalarının gelişimine 1şık tutmaktadır (Boschmann ve Kwan, 2008, s.150). 
Kentlerde nüfus artışı ile birlikte hareketlilik ihtiyacı da artmaktadır. 1970'li yıllardan bu yana kentlerde motorlu taşıt ve aynı zamanda özel otomobil sahipliği de giderek hızlanmıştır (Acar, 2003, s.44). Binek araçları, hafif yük kamyonları, son yirmi yıldır dünyanın en büyük taşımac1lığa bağlı karbon kaynakları olmuştur. Özellikle özel otomobillere olan talebin artması da bu miktarın artmasına katkıda bulunmaktadır (Tsay ve Herrmann, 2013, s.6). Hava ve gürültü kirliliği, trafikte yaşanan tıkanıklıklar ve kazalar, sonlu kaynakların tüketimi gibi durumlar artık motorlu ve özel araç odaklı taşımacılığın sürdürülemez olduğunu göstermektedir (Balsas, 2015, s.1).

Günümüzde gelişmiş ülkelerde kentlerde ve kent merkezlerinde otomobil odaklı yaklaşımdan uzaklaşıldığı ya da uzaklaşılma arayışı içinde olduğu görülmektedir (Acar, 2003, s.44). Özellikle gelişmiş ülkelerde, kentlerde otomobillere bağlı olmayan "modern yaklaşımlar" kabul görmeye başlamıştır. Bu yaklaşımların temelinde, yayalaştırma, cadde tasarımları hareketi gibi toplumsal halk hareketleri önem taşımaktadır. Yayayı öncelikli alan "yayalaştırma hareketi" ilk olarak 1950 ve 1960'lı yıllarda alışveriş merkezleri ve çevresi için ortaya konulmuş bir harekettir. $\mathrm{Bu}$ hareket elverişli bisiklet yolu alanları planlamasında önemli bir adımdır. Cadde tasarımları hareketi ise; 1970'li yılların sonlarına doğru William Whyte ve Donald Appleyard tarafından geliştirilmiş, "yaşanılabilir caddeler (livable streets)" kavramı olarak adlandırılmıştır. Temel yaklaşımı motorlu araçların, bisikletlerin ve yayaların aynı yolda beraberce nasıl hareket edeceklerini düzenlemektir (Asımgil, 2017, s.34). Bu nedenle gelişmiş ve son zamanlarda gelişmekte olan ülkelerde arazi kullanımı planlanması ile yolculukların kısaltılması, otomobil vb. motorlu araçlar dişındaki hareketlilik seçeneklerini destekleyen ulaşım politikalarının geliştirilmesi önem kazanmıştır (Acar, 2003, s.44).

Sürdürülebilirliği esas alan kent içi ulaşım planlarında; insanı odak alan öncelik sıralamasının yapılması zorunluluk haline gelmiştir. Bu öncelik sıralaması şu şekildedir (Acar, 2003, s.44).

1. İnsan - yayalar

2. Çevre dostu motorsuz ulaşım araçları

3. Toplu ulaşım araçları

4. Hareket halindeki taşıtlar

5. Park eden taşıtlar 
Sürdürülebilir kentler oluşturmak için toplu taşıma ve kentsel gelişim stratejilerinin belirlenmesi önemlidir. Ulaşımın toplumsal talep boyutunun; bireysel ölçekte (katlı yol, katlı kavşak, vb.) değil üst ölçekte bütüncül bir biçimde ele alınması gerekmektedir. Bütüncül bir ulaşım politikası bağlamında ulaşım ana planı kavramı da böyle bir ihtiyaçtan doğmuştur.

Türkiye'de günümüzde nüfusun üçte ikisinden fazlasının kentlerde yaşadığı görülmektedir. Kentleşme hızı artık düşmüş olsa da demografik değişim devam etmektedir. Kentlerdeki nüfus yoğunluğu ve özel araç sayısının artması özellikle kent merkezlerinde hava ve gürültü kirliliği, daha fazla enerji tüketimi ve trafikte tıkanıklık gibi olumsuzluklara neden olmaktadır (Akman ve Ataman, 2016, s.54). Yaşanan sorunların temel kaynağı kent ve ulaşım planlamada insan/yaya odaklı değil özel araç/otomobil odaklı yaklaşımların benimsenmesidir. Oysa kent içi ulaşımın temel amaçları bu gibi sorunların çözümü, ulaşım ihtiyacının karşılanması ve kentsel gelişimin sağlanması olmalıdır. Diğer bir deyişle kentleşme hızına paralel bir ulaşım altyapısının geliştirilmesi ideal olandır. Bu amaçlara ulaşmak için uygun çözümlerden biri de gelişmenin ve ekonomik büyümenin temel göstergelerinden biri olan toplu taşıma sistemlerine öncelik verilmesidir (Akman ve Ataman, 2016: 54).

Türkiye'de TÜIKK 2018 yılı verilerine göre toplamda otomobil sayısı 11.740.823 olup il bazında en fazla otomobil 275525 (kişi başına düşen otomobil sayısı 0.24) ile İstanbul'da kullanılmaktadır. Bunu Ankara, İzmir, Antalya ve Bursa takip etmektedir. Van'da ise 28010 (kişi başına düşen otomobil sayısı 0.05 ) otomobil kullanılmaktadır. Van'da otomobil kullanımı ülke geneline göre düşük görünmekle birlikte son yıllarda aldığı göç ve nüfus artışı ile kentte özellikle kent merkezinde trafik tıkanıklığı, otopark vb. ulaşım sorunlarında da artış görülmektedir. Buradan hareketle bu makalede Van kent merkezinde Van Büyükş̧ehir Belediyesi Ulaşım ve Koordinasyon Merkezi (UKOME) tarafından mevcut trafik yoğunluğunu azaltmak amacı ile kent merkezinin önemli caddelerinden Cumhuriyet Caddesi güzergâhının bir kısmının toplu taşım güzergâhı kapsamından çıkarılması ${ }^{1}$ ve parkomat uygulaması gibi düzenlemeler ele alınmaktadır.

\footnotetext{
${ }^{1}$ Yazar Van kent merkezinde toplu taşım güzergahlarının değiştirilmesi dava konulu 2487 Esas 548 nolu dava dosyasında tek bilirkişi olarak 03.04.2018 tarihinde görev almıştır. Çalışma, ilgili Idare Mahkemesinin onayı alınarak ilgili dava konusundan yararlanılarak geliştirilmiştir.
} 
Bu düzenlemelere ilişkin yaklaşım sürdürülebilir ulaşım politikaları bağlamında yasal, yönetsel ve mekânsal açıdan değerlendirilmektedir.

\section{Sürdürülebilir Kentsel Ulaşım/Ulaştırma}

Ulaşım insanların yer değiştirme ihtiyacı sonucunda araçlı veya araçsız olarak bireysel hareketlilik halleri olarak tanımlanabildiği gibi "insanların ve nesnelerin belirli bir amaca yönelik olarak bir yerden başka bir yere yer değiştirmeleri" olarak da tanımlanabilir (Akman ve Ataman, 2016, s.54). Şeremet ve Alaeddinoğlu'nun $(2018$, s.203) ifade ettiği gibi geçmişte ulaşımda hareketlilik basitçe yerler arasında hareket etme yeteneği olarak anlaşılmakta iken günümüzde hareketlilik farklılaşmakta ve yeni anlamlar

yüklenmektedir. Örneğin "erişebilirlik" kavramı hareketlilik özelliğine bağlı olmakla birlikte telefon bankacılığı gibi mal, hizmet ve mekânlara ulaşabilmenin farklı yöntemlerini içeren çok daha kapsamlı bir kavramdır (Şeremet ve Alaeddinoğlu, 2018, s.204). Ulaştırma kavramı ise insanların yer değiştirme, haber veya mal gönderme ihtiyaçlarını karşılamak için belirli bir taşıt veya teknoloji aracı kullanılarak kamu veya özel kurumlar tarafından bu hizmetin verilmesidir (Akman ve Ataman, 2016, s.55).

Kentlerde, sanayileşme, teknolojik gelişme ve ekonomik faaliyetlerle birlikte nüfus artmaktadır. Özellikle büyük kentlerde artan nüfus ile birlikte artan yapılaşma mekânsal büyüme olarak kendini göstermektedir. $\mathrm{Bu}$ nedenle ulaşım/kent içi ulaşım kentli nüfusun günlük faaliyetleriyle yakından ilişkili olup kentsel yaşamının önemli unsurlarından biridir (Akbulut, 2016, s.337). Kentsel ulaşım, "temel olarak kent sınırları içinde gerçekleşen yük, yolcu, araç ve yaya hareketlerini" kapsamaktadır. Kentsel ulaşım talebi çoğunlukla ev, iş, okul, sağlık, eğlence vb. odaklı seyahatlerin oluşturduğu taşıma ücreti, yolculuk süresi, konfor, sefer sıklığı, güvenlik vb. hizmet düzeyine ilişkin parametrelere bağlıdır. Hareketlilik ve ulaştırma talebi gelir ile doğru orantılıdır. İlaveten hem otomotiv sektöründeki gelişmeler, hem otomobil edinmeyi kolaylaştırıcı kredi v.b. uygulamalar da ulaşım talebini artırmaktadır (Akbulut, 2016, s.340).

1960'lı yıllarda ekonomik kalkınma ve çevre arasındaki ilişki tartışılmaya başlanmış ve 1970'li yıllarda da uluslararası düzeyde tüm dünya tarafından benimsenmeye başlamıştır. Böylece sürdürülebilirlik, sürdürülebilir kalkınma kavramları ortaya çıkmıştır. Sürdürülebilir kalkınma 
kavramı ile birlikte sürdürülebilirlik ulaştırma sektörü dâhil kalkınma ile ilişkili tüm alanlarda tartışılmaya başlanmıştır. Çünkü insanların, bir yere, mal ve hizmetlere erişimi sosyal ve ekonomik refah bakımından önem arz etmektedir (Cirit, 2014, s.8).

Sürdürülebilir ulaşım kavramının ortaya çıkmasında etkili olan başlıca hususlar şunlardır (Cirit, 2014, s.10):

- “1970'lerden itibaren kent içi karayolu ağının genişletilmesinin hava ve gürültü kirliliği gibi kentler üzerindeki olumsuz etkileri bunlara bağlı olarak karayolu ağırlıklı ulaşım planlamasının yarattığ1 kaygilar,

- Kentlerdeki ortalama trafik hızının düşürülmesi, yayalaştırılmış bölgelerin arttırılması ile trafikten kaynaklı kaza ve yaralanmaların, trafik sıkışıklığının azalması, yürüme ve bisiklet kullanımın artması, toplu taşıma ile daha fazla yolcu taşınması gibi olumlu sonuçların elde edilmesi,

- Sürdürülebilirlik konusunda farkındalığın artması."

Günümüzde sürdürülebilir kentsel ulaşım, gelişmiş ve gelişmekte olan her ülke ve kentin gündemindedir (Yiğitcanlar, Fabian ve Coiacetto, 2008, s.29). Gelişmekte olan ülkelerde ise, sürdürülebilirlik açısından kentsel ulaşım kritik öneme sahiptir (Şenbil, Fujiwara ve Zhang, 2007, s.1). Ancak ulaşımda sürdürülebilirlik ilkesi özellikle gelişmiş ülkelerde dikkate alınmaktadır. Bu ülkeler, trafik azaltımı, taşıma kapasitesinin verimli kullanımı açısından özel araç kullanımını sınırlamayı, toplu taşım, bisiklet ve yaya ulaşımını arttırmayı temel yaklaşım olarak benimsemektedir.

Sürdürülebilir ulaşım ilkesi çevresel ve ekonomik etkileri ile toplumsal eşitlik ilkesi açısından otomobili temel alan bir ulaşım sisteminin olumsuzluklarına dikkat çekmektedir (Sutcliffe a, 2009, Sutchliffe b, 2009, s.90). Sürdürülebilir ulaşım ile ilgili literatür çok geniştir ve esas olarak Avrupa, Kuzey Amerika ve Avustralya'dan gelmektedir. Alternatif ulaştırma modellerinden, uluslararası ulaşım sürdürülebilirliği uygulamalarına; sosyal değişim ve sürdürülebilir taşımacılıktan erişilebilirlik planlamasına ve hareketlilik yönetimi projelerinin etkilerine; sürdürülebilir taşımacılık ve yaşam kalitesinin yenilikçi yönlerine, akıllı ulaşım sistemlerine, ulaştırma ve arazi kullanımı planlama entegrasyonuna kadar uzanan geniş bir literatür bulunmaktadır (Yiğitcanlar, Fabian ve Coiacetto, 2008, s.29). 
Sürdürülebilir bir kentsel ulaşım sisteminde; kentsel alanın düzenlenmesi - arazi kullanım planlaması ve diğer alanlardaki eylemlerle ihtiyaçların karşılanması için daha iyi bir çözüm bulunması, motorsuz taşımacılığın azaltılmasıyla çevre üzerinde olumsuz etkinin azaltılması, birden fazla ulaşım modu kullanarak verimli seyahat sağlayan dengeli bir entegre ulaşım sisteminin geliştirilmesi, teknolojik standart ve yük dağıtım ve teslimat tesisleri ve hizmetlerinin organizasyonunun sağlanması amaçlanmaktadır. Buradan hareketle sürdürülebilir ulaşımın ana hedeflerinden biri; seyahat talebini azaltmak, sadece özel araçları değil aynı zamanda motorlu toplu taşımayı da içeren motorlu taşımacılık ile yapılan seyahatleri azaltmak ve bisiklet, yürüyüş gibi motorsuz taşımacılık miktarını arttırmaktır. Bunu başarabilmek için otomobil odaklı kentler tasarlamadan yaya ve bisiklet dostu kentlere yönelmeye başlamalıdır. Bu nedenle şehirlerin/kentlerin ulaşım planlaması ve arazi kullanım planlamasını bütünleştirmesi çok önemlidir (UNESCAP ve CITYNET, 2011, s.18).

Sürdürülebilir bir kentsel ulaşım hizmeti yaşanabilirliğin sağlanmasında yaşam kalitesinin dayandı̆̆ değişkenlerden biridir. Sürdürülebilir kent içi ulaşım kavramı genel olarak motorlu taşıt sayısının artış hızı, kentsel hava kirliliği, yol emniyeti, düşük gelir gruplarının ulaşım ihtiyaçları ile yaşlıların, engellilerin, kadınların ve çocukların ulaşım ihtiyaçlarını içermektedir. Kent içi ulaşımın sürdürülebilirliğinde iki temel engel bulunmaktadır. Birincisi geleneksel kent ve ulaşım planlamasının özel araç kullanımını teşvik edici olması, ikincisi ise ulaşım sisteminin yarattığı sorun ve maliyetlerin bireyler üzerinde adil olarak paylaştırılamamasıdır (Cirit, 2014, s.16). Otomobil sahipliğinin artması ve özellikle gelişmekte olan ülkelerde otomobillerin kat ettiği mesafelerin artmasıyla dikkat çeken hızlı motorizasyon; artan gelir seviyelerinden, otomobil üretiminde ortaya çıkan ulusal ekonomik büyüme stratejilerinden, özel otomobilin bir statü aracı olarak algılanmasından kaynaklandığı gibi kentlerde bireylerin özel otomobil sahipliğini azaltacak alternatif ulaşım modlarının sunulmasının yetersizliğinden de kaynaklanmaktadır (Tsay ve Herrmann, 2013, s.6). Araç dostu kentler; yürümek, bisiklete binmek için etkin toplu taşıma araçları veya güvenli alanlar sağlamadığında, kentliler giderek daha fazla enerji tüketen ve trafik sıkışıklığına neden olan otomobillere yöneliyorlar (Tsay ve Herrmann, 2013, s.7). Buna karşın özellikle gelişmekte olan kentlerde giderek daha fazla karayolu yapımına yönelik politikaların, hızlı 
motorizasyonun sürekli artan talebi ile başa çıkmada başarısız olduğu ve bir kısır döngü içinde olduğu açıkça görülmektedir (Neyastani, 2015, s. 5).

Ulaşım altyapısının özel araç/otomobil odaklı değil insanları dikkate alarak tasarlanması; bireyleri motorlu olmayan diğer taşıma yöntemlerini kullanmaya teşvik edecek ve kişisel motorlu taşıtlar ile yapılan yolculuk sayısını azaltacaktır (Boltze ve Tuan, 2016, s.207; Neyastani, 2015, s. 5; UNESCAP ve CITYNET, 2011, s.18). Literatürde, sürdürülebilir kentsel ulaşımın otomobil kullanımı azaltmak, genel sosyal eşitliği azaltmak, yaşam kalitesinin yükseltilmesi gibi sosyal boyutların (eşitlik, yaşam kalitesi) Avrupa ülkelerinde Amerika Birleşik Devletleri'ne göre daha fazla dikkate alındığı görülmektedir (Boschmann ve Kwan, 2008, s.138). Özellikle gelişmiş Avrupa ülkelerinde daha güvenli yürüyüş, bisiklete binme ve toplu taşıma araçlarına binme düzeyinin arttırılması öncelikli hedeflerdir. Bu hedefler hem ulusal, hem bölgesel hem de yerel yönetim düzeyinde olup, kar amacı gütmeyen kuruluşlar da olmak üzere tüm paydaşları, bu kamu politikalarının arttırılmasına yardımcı olmaktadır. (Balsas, 2015, s.1).

Kentsel ulaşım sistemi içinde toplu taşım sisteminin kesintiye uğraması yaşlı, genç, engelli ve kadın başta olmak üzere dezavantajlı insanların birçok temel ihtiyaca ulaşımını zorlaştırmaktadır. Öte yandan bireysel araç kullanımındaki artış da çocuk, yaşlı vb. diğer kullanıcılarının yaşam alanlarını sınırlandırmaktadır (Şeremet ve Alaeddinoğlu, 2018, s. 209). Günümüzde kat edilen mesafe, kapladıkları alan, harcadıkları enerji göz önüne alınarak (Balsas, 2015, s.1) kentlerde bireysel araç kullanımının giderek artmasının çevre, mekân ve sosyal yaşamı olumsuz yönde etkilediği kabul edilen bir gerçektir (Şeremet ve Alaeddinoğlu, 2018, s.209).

Sürdürülebilir kent içi ulaşımı bağlamında toplumun tüm bireylerine eşit erişim imkânı sunan, toplu taşımayı ve motorsuz ulaşım alternatiflerini ön planda tutan, diğer ulaşım türleri(modları) ile entegrasyonunu sağlayan kapsamlı bir kent içi ulaşım sisteminin oluşturulması ideal olandır. Günümüzde hem gelişmiş hem de gelişmekte olan ülkelerde sürdürülebilir ulaşım sistemleri oluşturulması hususunda çabalar gösterilmekte ve çeşitli politikalar uygulanmaktadır (Cirit, 2014, s.23). Örneğin son 1015 yıldır Hindistan, Meksika, Brezilya gibi ülkeler hızlı nüfus artışı ve beraberinde artan motorlu taşı//özel araç sahipliği ile birlikte ortaya çıkan 
zorlukları çözebilmek için ulusal kentsel ulaşım politikaları oluşturdular (Tsay ve Herrmann, 2013, s.53). Literatürde sürdürülebilir kent içi ulaşım politikaları çekme ve itme politikaları şeklinde iki biçimde tanımlanmaktadır. Toplu taşımanın cazip hale getirilerek bireylerin toplu taşımaya yönelmesini sağlayacak politikaların geliştirilmesi çekme politikaları iken otomobil kullanımını caydırmaya yönelik politikalar itme politikaları olarak tanımlanmaktadır. Çekme politikalarının amacı otobüs, metrobüs ve raylı sistemler gibi toplu taşıma ve motorsuz ulaşım gibi ekonomik, çevresel ve sosyal anlamda birçok faydası olan ulaşım türlerinin yaygınlaşmasını sağlamaktır. İtme politikalarının amacı ise otomobil kullanımını azaltılmasını sağlamak olduğu için yol/yoğunluk ücretlendirme, park yönetimi, trafik yavaşlatma ve taşıt/yakıt vergilerinin düzenlenmesi gibi ekonomik tedbirlerden oluşmaktadır. Bu politikaların bir arada dengeli bir şekilde uygulanması ile etkin sonuçlara ulaşılabileceği göz ardı edilmemelidir (Cirit, 2014, s.23).

\section{Van Kent İçi Ulaşım Sisteminde Toplu Taşıma Güzergâhının Değişti- rilmesinin Mevzuat ve Mekânsal Açısından Değerlendirmesi}

Bu bölümde Van Büyükşehir Belediyesi Ulaşım ve Koordinasyon Merkezi (UKOME) tarafından kent içi ulaşım sistemindeki sorunlara çözüm olarak kent merkezindeki düzenleme kararları ele alınmaktadır. Ancak öncelikle Türkiye'de büyükşehir kent içi ulaşım sisteminin düzenlenmesinde bağlayıcı ilgili yasa ve yönetmelikler aktarılmaktadır. İlk olarak yasal yönetsel çerçevenin ele alınması konu bütünlüğü ve konunun ele alınış amacı açısından önemlidir. Böylece Van kent merkezi özelinde kent içi ulaşım sistemindeki ilgili düzenleme ve temel aksaklılar sürdürülebilir kent içi ulaşım politikaları bağlamında değerlendirilip tartışılabilmektedir.

Yasal, Yönetsel ve Mekânsal Açısından Değerlendirme

Türkiye'de özellikle büyük kentlerdeki ulaşım planlamasıyla ile ilgili düzenlemelerin İmar Kanunu gibi genel kanun düzenlemesini gerektirecek şekilde etkin olamadığı görülmektedir. Türkiye Belediyeler Birliği'nin Ulaşım Planlama Çalışmaları Ve Ulaşım Ana Planı Hazırlama Kılavuzu'na göre Türkiye'de genel olarak Ulaşım Planlama Çalışmaları üç ana başlık altında sınıflanmaktadır. Bu ana başlıklar şunlardır (TBB, 2016, s.4): 
- “Ulașım Ana Planı Hazırlanması: Mekânsal plan kademeleri eşgüdümlü ve uyumlu, detaylı anket, sayım vb. saha araştırmaları, ulaşım talep tahmin modellerinin hazırlanması ve alternatif planların üretilmesi sürecidir. Bu nedenle söz konusu çalışmaların belirtilen nitelikte hazırlanması için öncelikle 250.000 nüfus üzerindeki belediye ve büyükşehir belediyelerinin yapması, 100.000 üzeri ve 250.000 altındaki belediyelerin ise daha öncelikli olarak kısa vadeli planlama çalışmaları yapmasının hem ekonomik hem zaman hem de teknik olarak daha rasyonel olacağı öngörülmektedir."

- "Acil Eylem Ulașım ve Trafik Iyileștirme Plan, Etüt ve Projelerinin Hazırlanması: Kısa vadeli çözüm önerilerini içeren düzenlemelerdir. Kentin ulaşım ve trafik sistemindeki mevcut sorunların ve yetersizliklerin çözümüne yönelik, ulaşım ve trafik düzenlemeleridir. Bu çalışmalar ulaşım ana planı çalışmalarına alternatif olmayıp başlangıç için atılması gereken adımları belirleme amaçlı çalişmalar olarak öngörülmektedir."

- "Raylı Sistem/Metrobüs/Kablolu Sistem Hatları Ön/Kesin Projeleri ve Fizibilite Etütlerinin Hazırlanması: Ulaşım ana planında toplu taşıma planlaması kapsamında önerilen raylı sistem, metrobüs, ya da kablolu sistem hatlarının olması durumundan, ulaşım ana planlarının onaylanması sonrasında Ulaştırma, Denizcilik ve Haberleşme Bakanlığı Altyapı Yatırımları Genel Müdürlüğ̈̈'nün yayınladığı tasarım kriterlerine göre hazırlanacak projelendirme ve mali ekonomik açıdan uygulanabilirliğinin değerlendirilmesi çalışmaları, olarak öngörülmektedir."

Yukarıda bahsi geçen ulaşım planlama çalışmalarının yasal ve yönetsel çerçevesini temel olarak, Mekânsal Planlar Yapım Yönetmeliği, 5393 Sayılı Belediye Yasası, 5216 Sayılı Büyükşehir Belediyesi Yasası ve ilgili yönetmelikler belirlemektedir. Bu bağlamda ilgili yasal ve yönetsel çerçeve değerlendirildiğinde; 2014 yılında yürürlüğe giren Mekânsal Planlar Yapım Yönetmeliğinin mekânsal planlama ve kademe ilişkilerinin tanımlandığı 6. Maddenin 1. Fikrasına göre "Mekânsal planlar kapsadıkları alan ve amaçlar açısından Mekânsal Strateji Planlarl, Çevre Düzeni Planları ve İmar Planları olarak hazırlanır. Buna göre planlama kademeleri, üst kademeden alt kademeye doğru sırasıyla; Mekânsal Strateji Planı, Çevre Düzeni Planı, Nazım Imar Planı 
ve Uygulama İmar Planından oluşur." denilmektedir. Diğer bir deyişle ilgili yönetmelik bağlamında her plan kademesinin tanımı detaylı bir biçimde incelendiğinde bir üst kademe planın bir alt kademe planın bağlayıcısı olduğu; ulaşım ilişkileri ve ulaşım sistemine ilişkin ifadelerin hem stratejik hem mekânsal ölçekte "tanımlar" içinde yer aldığı ve bunların plan bütününden ayrı değerlendirilemeyeceği ifade edilmektedir. Öte yandan Mekânsal Planlar Yapım Yönetmeliğinin 4. Maddesinin (i) bendinde de "ulaşım ana planı" kavramının yerini bulduğu ancak yukarıda bahsi geçen plan kademelenmesinin içinde yer almadığı görülmektedir. Yönetmelikte yer alan tanıma göre ulaşım ana plan "şehrin mekânsal, sosyal ve ekonomik özelliklerine göre ulaşım ihtiyaç ve talepleri ile sürdürülebilir gelişmeyi dikkate alarak; şehir ve yakın çevresinin ulaşım sistemini, ulaşım ağını, standart ve kapasiteleri ile ulaşımın türlere dağılımını, kara, deniz ve hava ulaşımı ve bu ulaşım türlerinin birbirleriyle entegrasyonu, bu türlere ait transfer noktalarm, depolama ve aktarma merkezlerini, ticari yük koridorlarım ve toplu taşıma güzergâhları ile gerektiğinde otopark, bisiklet ve yaya yolları, erişilebilirlik ve trafik konularında gereken ayrıntıları belirleyen, toplu taşımaya ağırlık veren ve öncelikli kılan, kısa ve uzun dönemde ulaşım türlerine ait sorunlara çz̈̈üm önerilerini ortaya koyan, gerektiğinde şehrin üst ve alt kademe planlarn ile eşgüdümlü olarak hazırlanabilen, plan paftası ve raporuyla bir bütün olan planı" olarak tanımlanmıştır.

Genel olarak bir ulaşım ana planı çalışması; "kent içi ulaşımın, nazım imar planı kararları kapsamında yer alan strateji ve gelişme önerileri çerçevesinde yeniden çözümlenmesi, ulaşım ve trafik altyapısı ve işletmeciliğinin yeniden düzenlenmesi, toplu ulaşım sistemlerine öncelik verilerek, kentte günümüzde yaşanan ve gelecekte oluşması beklenen ulaşım sorunlarının uzun vadeli yaklaşımlar ile çözümüne yönelik geliştirilen planlama karar ve ilkelerinin bütününü kapsamaktadır" biçiminde tanımlanmaktadır. Buradan hareketle Mekânsal Planlar Yapım Yönetmeliğinin (Madde 10) uygulama imar planlarının hazırlanması sürecinde yapılan analiz ve araştırmalar kapsamında ulaşım ile ilgili olarak yapılması gereken analiz ve araştırmalar şunlardır: "Ulaşım sistemi ve kademelenmesi, durak-istasyon noktaları, trafik düzeni ve güvenliği, yollar ve kavşaklar ile ilgili ilkeler, yapı ve tesislerden karayoluna geçiş yolu bağlantısı yapılabilecek kesimler, yaya bölgeleri, yaya ve bisiklet yolları,otopark kapasitesi ve dağılımı, ulaşım güzergâhları, havalimanı, liman ve iskeleler, gar ve istasyon alanları, lojistik alanlar." İlaveten aynı Yönetmeliğin 12. Maddesine göre; "İmar planlarında araç 
trafiğinin azaltılması, toplu taşıma ve yaya öncelikli bir ulaşım sisteminin kurgulanması esastır. Toplu taşım araçlarının kullanımının teşvik edilmesi amacıyla park et - devam et sisteminin yayginlaştırılmasına ve toplu taşım duraklarının veya istasyonlarının bulunduğu etki alaninda otopark alanları ayrilması ve birbirine entegre olmasına ilişkin imar planlarında kararlar getirilir."denilmektedir.

Belediye teşkilatına kentiçi ulaşımın sağlanması ve bunun sağlıklı bir şekilde işletilerek, belediye sınırları içinde ulaşım hizmetlerinin sunulmasında önemli görev ve sorumluluklar ile yetkiler yürürlükte olan 5393 ve 5216 sayılı yasalar ile tanınmaktadır. 5393 sayılı Belediye Yasasının Madde 15 (f) bendine göre; "MADDE 15. -Belediyenin yetkileri ve imtiyazları şunlardır: f) Toplu taşıma yapmak; bu amaçla otobüs, deniz ve su ulaşım araçları, tünel, raylı sistem dâhil her türlü toplu taşıma sistemlerini kurmak, kurdurmak, işletmek ve işlettirmek" belediyenin yetki ve imtiyazları arasındadir.

5216 sayılı Büyükşehir Belediyesi Yasasının Madde 7 (f) bendine göre ise; "Büyükşehir ulaşım ana plânını yapmak veya yaptırmak ve uygulamak; ulaşım ve toplu taşıma hizmetlerini plânlamak ve koordinasyonu sağlamak; kara, deniz, su ve demiryolu üzerinde işletilen her türlü servis ve toplu taşıma araçları ile taksi sayılarm, bilet ücret ve tarifelerini, zaman ve güzergâhlarmı belirlemek; durak yerleri ile karayolu, yol, cadde, sokak, meydan ve benzeri yerler üzerinde araç park yerlerini tespit etmek ve işletmek, işlettirmek veya kiraya vermek; kanunlarn belediyelere verdiği trafik düzenlemesinin gerektirdiği bütün işleri yürütmek" büyükşehir belediyesinin görev, yetki ve sorumlulukları arasındadır.

Ayrıca 5627 sayılı Enerji Verimliliği Kanunu bağlamında 09.06.2008 tarih ve 26901 sayılı Resmi Gazetede yayımlanan Ulaşımda Enerji Verimliliğinin Artırılmasına İlişkin Usul ve Esaslar Hakkında Yönetmelikte de bu konuda düzenlemelere yer verilmiştir. Yönetmeliğin "kentsel ulaşım planları" başlı̆̆ı altında; "Madde 10 - (1) Büyükşehir belediyeleri ve büyükşehir belediyesi sınırları dışındaki belediyelerden Nüfusu yüz binin üzerinde olanlar ulaşım ana planı hazırlarlar. Bu planlar on beş yıllık süreler için yapılır ve her beş yılda bir yenilenir. Şehir planlar ile sürdürülebilir kentsel ulaşım planları birlikte ele alınır." denilmektedir.

Böylece ulaşım ana planında hem sorumluluğun yerel yönetimlerde olduğu hem de mekansal planlarla eş güdümlü ve aynı zamanda 
sürdürülebilir olması hususu yinelenmektedir. İlaveten Mekânsal Planlar Yapım Yönetmeliğinin yanı sıra kent ulaşımı açısından bir ulaşım ana planı yapımının yerel yönetimlerin yetki ve sorumlukları arasına dâhil edilmesi; ulaşım ana planının önemini ve bunun ulusal politikalara yansıdığını göstermektedir.

5216 Sayılı Büyükşehir Belediyesi Yasasının Ulaşım Hizmetleri başlı̆g 1 altında "Ulaşım hizmetleri Madde 9- (Değişik birinci fikra: 12/11/2012-6360/8 md.) Büyükşehir içindeki kara, deniz, su, göl ve demiryolu üzerindeki her türlü taşımacılık hizmetlerinin koordinasyon içinde yürütülmesi amactyla büyükşehir belediye başkanı ya da görevlendirdiği kişinin başkanliğında, yönetmelikle belirlenecek kamu kurum ve kuruluşlar ile, Türkiye Şoförler ve Otomobilciler Federasyonunun görevlendireceği ilgili odanın temsilcisinin katılacă̆ı Ulaşım Koordinasyon Merkezi(UKOME) kurulur" denilmektedir. UKOME içinde yer alacak temsilciler (Büyükşehir Belediyesi, Milli Savunma Bakanlı̆̆ı, Jandarma Genel Komutanlığı ve ilgili kamu kurum kuruluş ile meslek odaları temsilcileri vb.) Madde 17'de detaylı bir biçimde yer almaktadır.

5216 Sayılı Büyükşehir Belediyesi Yasası 18. Madde bağlamında; "(1) UKOME; a) Büyükşehir belediyesinin sıntrlar içinde; b) Büyükșehir belediye ve mücavir alan sınırları içinde nazım plan çerçevesinde, arazi kullanım ve ulașım planlama çalıșmalarıyla büyükșehir ulașım planını yapmak, yaptırmak, uygulamak ve uygulatmak için gereken karar ve tedbirleri almakla, c) Trafiğin düzenli bir şekilde akımını sağlamak bakımından alt yapı hizmetleri ile ilgili tedbirleri almak, trafikle ilgili sorunları çözümlemek, trafikle ilgili olarak ülkeyi ilgilendiren veya mevzuat değişikliği gerektiren hususlar İçişleri Bakanliğına iletmekle, ç) Kara, deniz, göl, nehir, kanal ve demiryolu üzerinde işletilen her türlü servis ve toplu taşıma araçlar ile taksi sayılarm, bilet ücret ve tarifelerini, zaman ve güzergâhlarım belirlemek; otobüs, taksi, dolmuş ve servis durak yerleri ile karayolu, yol, cadde, sokak, meydan ve benzeri yerler üzerinde araç park yerlerini tespit etmek, gerçek ve tüzel kişiler ile resmi ve özel kurum ve kuruluşlara ait otopark olmaya müsait boş alan, arazi ve arsalarn geçici otopark yeri olarak ilan etmek ve bunların sahiplerine veya üçüncü şahıslara işletilmesi için izin vermek, izin verilen otoparklar ile karayolu üzerindeki diğer park yerlerinde özürlüler için işaretlerle belirlenmiş bölümler ayrılmasını sağlamakla, d) Karayolu taşımacılı̆̆ına ait mevzuat hükümleri saklı kalmak üzere, trafik düzeni ve güvenliği yönünden belediye sınırlar içinde ticari amaçla çalıştırlacak yolcu ve yük taşıtlar ile motorsuz taşıtların çalışma şekil ve şartları ile bu taşıtların teknik 
özelliklerini tespit etmek, çalıştırılabileceği yerler ile güzergâhlarını tespit etmek ve sayılarm belirlemek, bunlara izin ve çalışma ruhsatı vermekle, e) Büyükșehir belediyesinin sinırları içinde, ulașım, toplu tașıma ve trafik mevzuatının büyükșehir belediyesine verdiğ $i$ yetki doğrultusunda uygulamaya yönelik yönlendirici karar almak ve görüs olușturmakla, f) İlçe ve ilk kademe belediyelerce düzenlenen yol ve kavşaklar ile büyükşehir belediyesince yapilan sinyalizasyon sistemlerinde aksaklık tespit edildiği takdirde uyarıda bulunmak ve düzeltilmesini să̆lamakla, g) Büyükşehir belediyesinin sınırları içinde kalan karayollarının bir kısmının veya tamamının yoldan faydalananların bir kısmına veya tamamına kapatılmasına, park edilecek yerler ile zaman ve süresinin ve araçların geliş ve gidiş yollarının ve yollara konulacak trafik işaretlerinin yerlerinin belirlenmesine karar

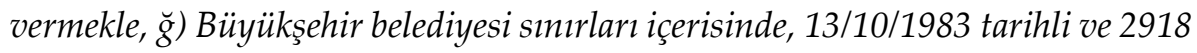
sayılı Karayolları Trafik Kanunun belirlediği sınırlar içinde araçların kullanacă̆ı şeritleri ve yol kullanım esasların tespit etmek ve gerekli yasakları koymak, gerekli hal ve yerlerde en çok ve en az hiz limitlerini belirlemekle, görevli ve yetkilidir" denilmektedir.

Son olarak aynı yönetmeliğin ulaşım hizmetlerine ilişkin işlemlerde Madde 28'e göre ise; "(1) Nüfus artıșı ve șehrin ulașım planı dikkate alınmak suretiyle büyükșehir sinırlan dâhilinde tașıma ihtiyacı, UKOME tarafindan düzenlenecek bir raporla İçișleri Bakanlığına bildirilir. (2) Taksi, dolmuş, minibüs ve umum servis araçlar ile toplu taşım araçlarımın tahsis süreleri, ticari plaka sayıları ile bu plakaların verilmesine ilişkin usul, esas ve devir ücretleri UKOME'ce tespit edilir." denilmektedir.

\section{Van Kentsel Ulaşım Sistemi}

Van, Anadolu'nun en büyük kapalı havzası olan Van Gölü kıyısında konumlanmış, birçok medeniyete ev sahipliği yapmış bir yerleşim merkezidir. 2011 yılında yaşanan depremler(23 Ekim ve 9 Kasım) kent planlama açısından yeniden yapılanma sürecini de beraberinde getirmiştir. İlaveten 2012 yılında 6360 Sayılı Yasa ile 13 ilçe büyükşehire dâhil edilmiştir. Böylece il sınırları ile büyükşehir sınırları örtüşmüştür. 2018 yılı TÜIKK nüfus verilerine göre il nüfusu 1.123.784 olup il dışından (çevre il ve ilçelerden) aldığı göç ile özellikle kent nüfusu artmaktadır. Bu nüfusun yaklaşık \%60'nı kentsel nüfus oluşturmakta ve ağırlıklı olarak üç merkez ilçede toplanmaktadır. Bu merkez ilçelerden İpekyolu'nun nüfusu 300.796, 
Edremit'in nüfusu 124.375 ve Tuşba'nın nüfusu da 156.717 'dir. Nüfus artışına paralel olarak nüfus yoğunluğu artmaktadır.

Ulaşım politikalarının temel amacı ulaşım ve trafik sorunlarına yönelik çözümlerin üretilmesidir. Sürdürülebilir kent içi ulaşım politikalarının temel amacı ise toplumun tüm bireylerine eşit erişim imkânı sunan, toplu taşımayı ve motorsuz ulaşım alternatiflerini ön planda tutarak her türlü ulaşım türleri ile entegrasyonunu sağlamaktır. Bu politikaların hayata geçirilmesinde en etkili araçlardan biri de özellikle büyükşehir belediyelerinin hazırlaması gereken ve son zamanlarda sıkça bahsedilen kentin mekânsal plan (nazım imar planı ve uygulama imar planı) kademeleri ile uyumlu ve eş zamanlı olması gereken ulaşım ana planıdır.

TÜİK 2018 yılı verilerine göre Türkiye genelinde Van'da kişi başına düşen otomobil sayısı 0.05 oran ile düşük görünmekle birlikte son yıllarda aldığı göç, nüfus artışı ve özel araç sahipliğine yönelim özellikle kent merkezinde trafik tıkanıklığı, otopark vb. ulaşım sorunlarında artışa neden olmaktadır. Van kenti geçmişten günümüze, kentsel ulaşım politikaları ve sistemini oluşturan bir ulaşım ana planına sahip değildir. 2011 yılı depreminden önce Van kent içi ulaşımına ilişkin sorunlar, sayısal veriler (trafik değerleri, yolculuk talepleri, trafik sayım ve etütleri, yolcu ve araç sayım ve anketleri vs) olmadan ulaşım etüt ve projeleri olmadan günübirlik politikalarla çözülmüştür (Ürün, 2015:42). Günümüzde ise kentte, özellikle ulaşım ve trafik sorunlarının görüldüğü kent merkezinde; otopark yapımı, kavşak düzenlemesi, parkomat uygulaması, sinyalizasyon ve toplu ulaşım güzergâh değişikliği gibi geçici ve noktasal çözümlerin uygulandığı görülmektedir. Bu düzenlemeler ve ulaşıma ilişkin alınan birçok karar sayısal veriler (trafik değerleri, yolcu ve araç sayım ve anketleri vs) olmadan yapılmaktadır.

Kent içi ulaşım genel olarak karayolu, demiryolu ve denizyolundan sağlanmaktadır. Bu bağlamda toplu taşıma sistemleri de karayolu, raylı sistem ve deniz yolu olmak üzere üç alt türde sınıflandırılmaktadır. Taşıma türlerinin hizmet alanları ve tercih edilme nedenleri birbirinden farklı ve her bir türün diğerlerine göre avantajları ve dezavantajları olabilmektedir (Akbulut, 2016, s.343). Türkiye'de kent içi ulaşımın belkemiğini karayolu sağlamaktadır. Otobüsler daha az altyapı yatırımları gerektirdiğinden ve tek bir hat üzerinde yolcu taşıma zorunluluğu bulunmadığından kent içi yolcu taşımacılığında en çok kullanılan toplu taşıma 
araçlarıdır. Dolmuş ve minibüs ise ara yolcu taşıma sistemleri olarak kullanılmakta ve taşıma sisteminin yeterli olmadığı Türkiye gibi ülkelerde geniş insan kitlelerinin otobüs duraklarında beklemelerini önlemek amacryla tercih edilmektedirler (Akman ve Ataman, 2016, s.55). Van kent içi ulaşım sistemi de karayolu ile sağlanmaktadır.

Van'da özel araç kullanımı Türkiye ortalamasının altında kalsa da özel araç sahipliğine yönelim olduğu görülmektedir. Bireylerin eğilimi dışında bunun en büyük sebeplerinden biri yerel yönetimin ideal bir toplu ulaşım politikası uygulayamamış olmasıdır. Kentte ulaşımın tamamı motorlu araçlar ile sağlanmakta olup çevreye duyarlı alternatif ulaşım modları da bulunmamaktadır. Diğer taraftan topografik olarak iç deniz ulaşımı ile yaya ve bisiklet ulaşımına uygun olduğu halde yaya öncelikli bir ulaşım politikası olmadığı görülmektedir (Ürün 2015, s.44). Kentte bu politikaların yansımalarının en fazla hissedildiği alan kent merkezidir. Van kent merkezi, kamu binaları, ofisler, dükkânlar, bankalar ve diğer faaliyet alanları iç içe geçmiş her yaş ve her kesimden tüm kentli tarafından kentin en yoğun kullanılan alanıdır. Bu nedenle trafik sıkışıklığı, gürültü kirliliği vb. ulaşım ile ilgili sorunların da en fazla yaşandığı alandır. Van kent bütünün yol kademelenmesi Şekil 1. de görüldüğü gibidir.

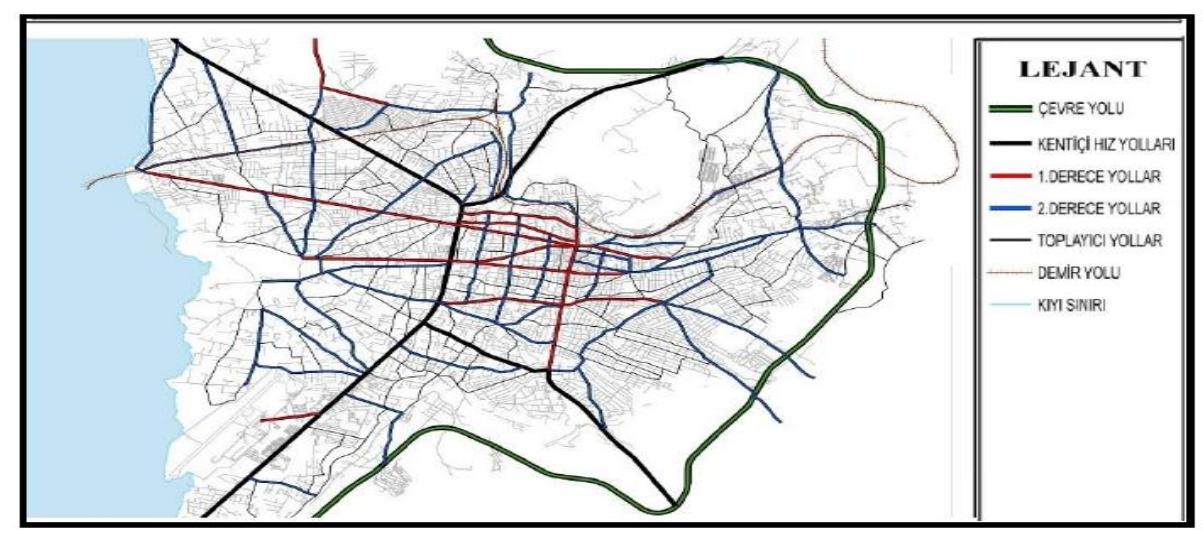

Şekil 1. Van Kent İçi Yol Kademelenmesi (a) (Ürün, 2015, s.56)

İpek Yolu Bulvarı ve Şabaniye Caddesi kent içi hız yolu, kentin ana arterlerini oluşturan Melen Caddesi, Üçevler Caddesi, İskele Caddesi, İki Nisan Caddesi Cumhuriyet Caddesi, Kazım Karabekir Caddesi, vb 
caddeler 1. Derece Yol, taşıt hızı ve yol altyapısı göz önüne alınarak Zübeyde Hanım Caddesi, Eski Cezaevi Caddesi vb caddeler 2. Derece Yol, 2. Derece Yolları erişim yollarına bağlayan yollar ise toplayıcı yol olarak ifade edilmiştir (Şekil 2).

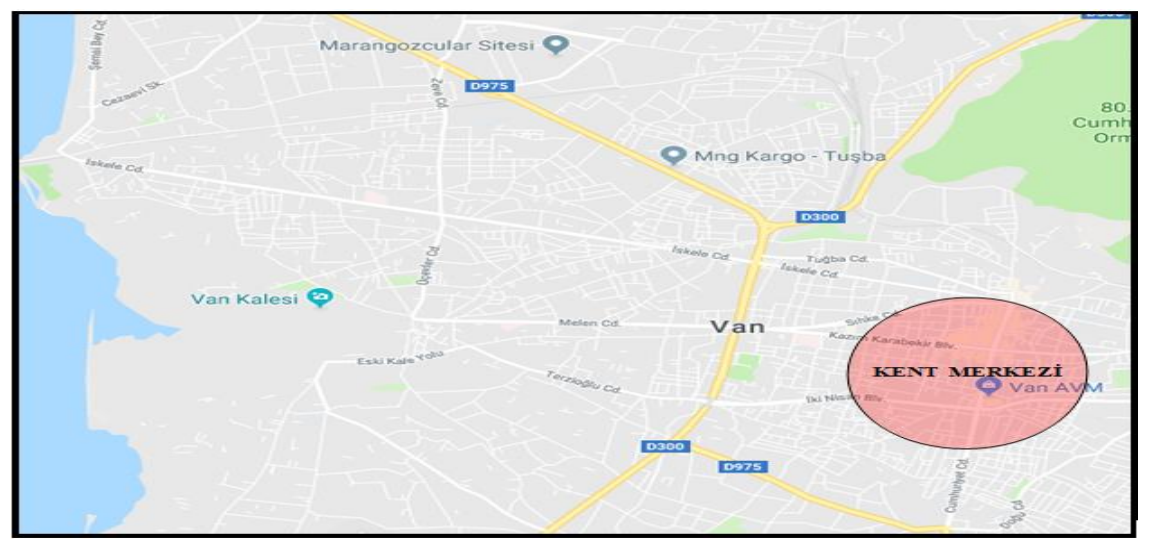

Şekil 2. Van Kent İçi Yol Kademelenmesi ve Kent Merkezinin Konumu (b) (googlemap görüntüsünden yararlanılarak oluşturulmuştur.)

2011 yılında meydana gelen depremler sonrasında merkez çeperinde toplu afet konutları yapılarak yeni yerleşim merkezleri oluşturulmuştur. Toplu Konut İdaresi (TOKi) tarafından kısmen kentin çeperlerinde (Akköprü) inşa edilen bu kalıcı konutlar ve bazı resmi kurumların yer seçimleri kentin makroformunda değişime neden olmuştur (Şekil 3). Bu yeni yerleşim merkezlerine bağlı olarak yeni yollar ve yeni güzergâh ihtiyaçları doğmuştur. Böylece kent merkezi ve yakın çevresinin dışında da bir hareketlilik ortaya çıkmıştır. Kent makroformu ulaşım türleri arasında bir entegrasyonu gündeme getirmiş ancak kentte akıllı ulaşım sistemleri altyapısı bulunmadığından türler arası aktarma olanağı da bulunamamıştır (Ürün, 2015, s.79). İlaveten 2013 yılı itibariyle On Dört İlde Büyükşehir Belediyesi ve Yirmi Yedi İlçe kurulması İle Bazı Kanun ve Kanun Hükmünde Kararnamelerde Değişiklik Yapılması Hakkındaki 6360 sayılı Kanunla Van İlinde Büyükşehir Belediyesi kurulmuştur. Van'ın Büyükşehir Belediyesi olmasına bağlı olarak da mevcut ulaşım sistemine doğrudan yansıyacak kentsel fonksiyonlarda da değişmeler meydana gelmiştir (Görentaş, 2015, s.5). 


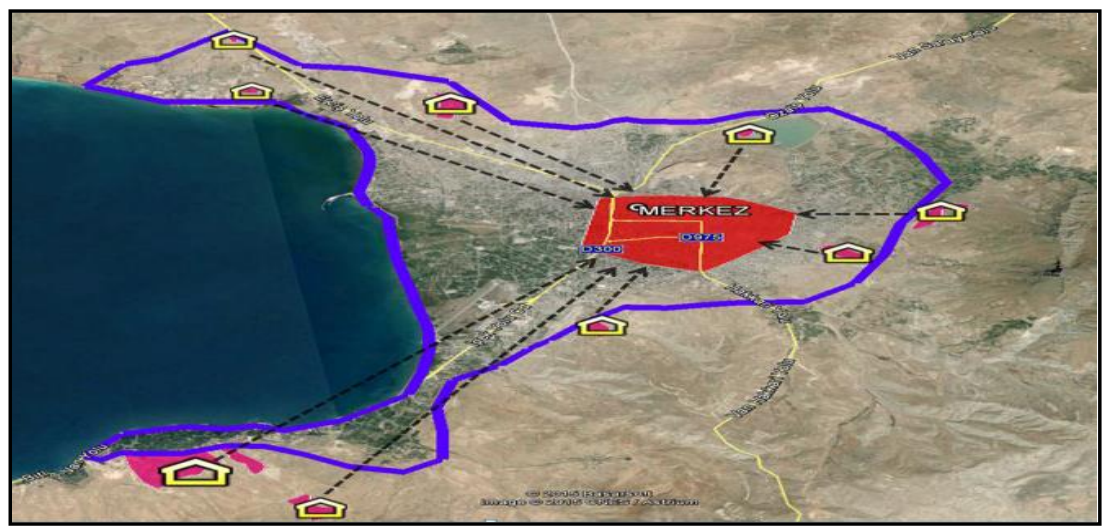

Şekil 3 . 2011 yılı depremi sonrası kalıcı konutların inşa edilmesi ve kentin değişen makraformu (Ürün, 2015, s.67)

Güncel olarak kentte, kent içi toplu ulaşım sistemi özel girişim (minibüs ve halk otobüsü) ve kamu (belediye otobüsü) eli ile gerçekleştirilmektedir. (Şekil 4, Şekil 5 ve Şekil 6). Şekil 4, Şekil 5 ve Şekil 6'da görülen Van Büyükşehir Belediyesi UKOME birimi tarafından ilgili yönetmelikler çerçevesinde hatlar ve renkler tanımlanmıştır. Söz konusu güzergâhlar kentin değişen makroformu açısından değerlendirildiğinde Van kent içi toplu taşım sisteminde kamunun (belediyenin) ulaşım/erişebilirlik hizmetlerinin sağlanması hususunda özel girişime(minibüs ve özel halk otobüsü) göre daha geniş bir alana hizmet verdiği görülmektedir.

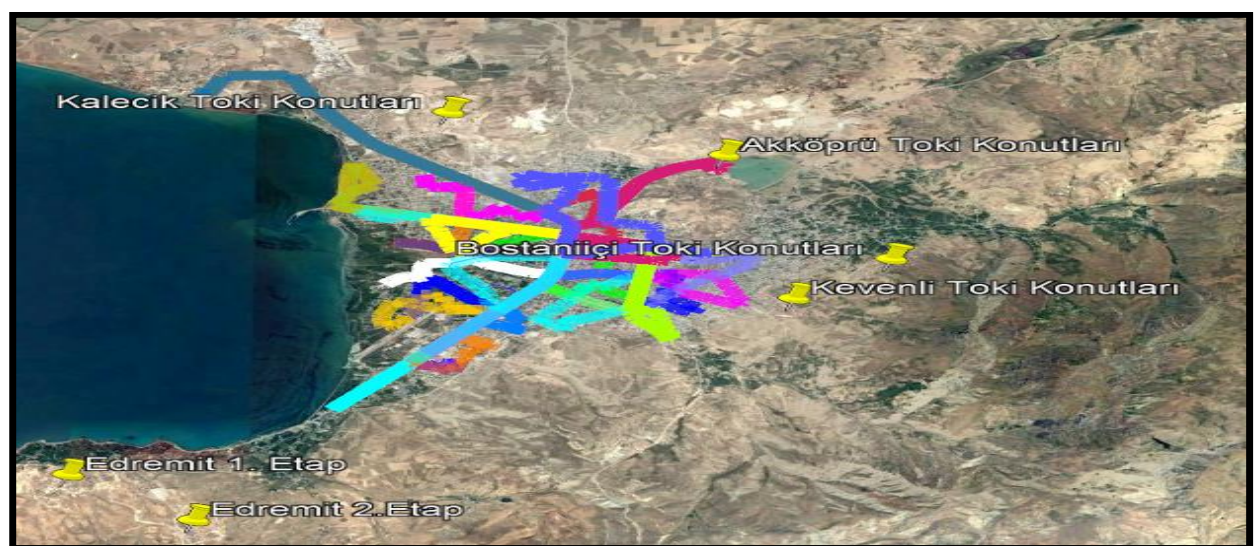

Şekil 4. Halk otobüsü güzergâhı (H) plakalı (2018-2019) 

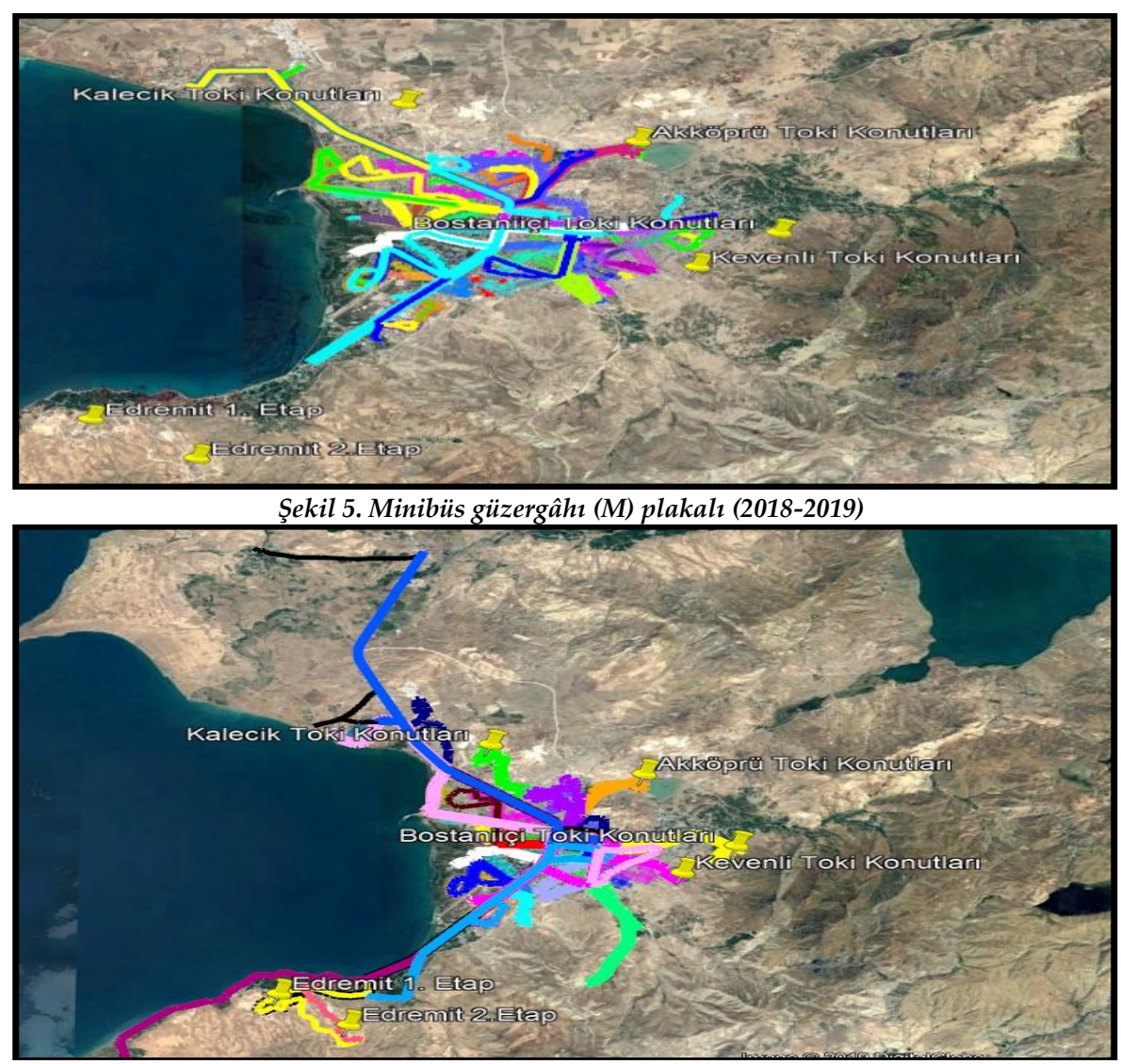

Şekil 6. Belediye Otobüs Güzergâhı (2018-2019)

\section{Van Kent Merkezinde Kent İçi Ulaşım Sistemine İlişkin Düzenlemeler}

Merkezi iş alanları (MİA), ticaret yoğunluğunun çok olduğu bölgeler olup aynı zamanda içerisinde lokanta, çarşı, çok katlı mağaza, banka, otel, sinema, tiyatro gibi sosyo-kültürel tesisler, yönetimle ilgili tesisler, özel eğitim ve özel sağlık tesisleri ve benzeri yapılar barındırır. Van kent merkezi İpekyolu ilçesinde Cumhuriyet Caddesi ve etrafında gelişmiştir. Van kent merkezinin en önemli caddeleri Cumhuriyet ve tamamı Maraş Caddesi olarak adlandırılan Kazım Karabekir Bulvarı ve onun devamı niteliğinde Mareşal Fevzi Çakmak Caddesi'dir. Bu caddeler mevcut ulaşım sisteminin 
ve merkezi iş alanının omurgasını oluşturmaktadır. Merkezi iş alanı (MİA) içinde yer alan, merkez ve merkez çevresindeki fonksiyonlara erişimde sıkça kullanılan caddelerdir. MİA içerisindeki kamu kurumları; Hükümet Konağı, Merkez Bankası, İl Kültür Turizm Müdürlüğü, Tapu ve Kadastro Müdürlüğü, Tuşba ve İpekyolu Nüfus Müdürlükleri'dir. Ayrıca tüm bankalar, ticari amaçlı dükkânlar ve en büyüğü Van AVM olmak üzere, Turkuaz, Artos, Aydın Perihan AVM ve City Van AVM olmak üzere 5 alışveriş merkezi (AVM) bulunmaktadır (Şekil 7).

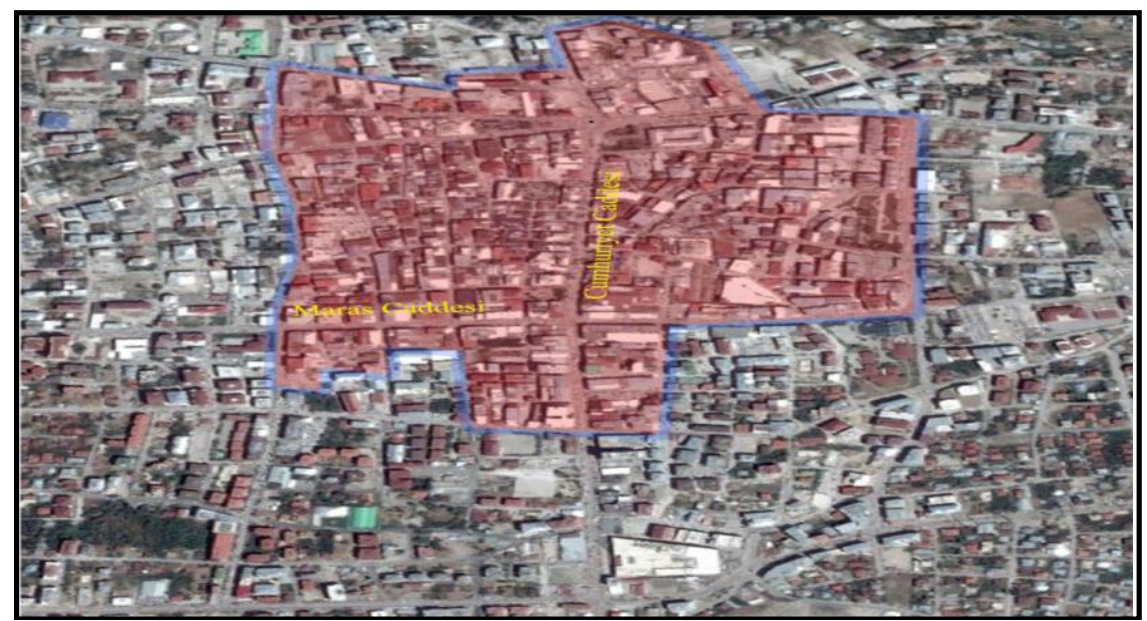

Şekil 7. Van Kent Merkezi İş alanı (MİA) ve yakın çevresi (Arpa, 2018, s. 72).

Yukarıda bahsi geçen yasa ve yönetmelikler bağlamında en temel vurgulardan birinin "ulaşım ana planı" kavramı olduğu görülmektedir. Bir büyükşehir belediyesi olarak Van Büyükşehir Belediyesi'nin 2004 y1l 5216 Sayılı Büyükşehir Yasası bağlamında imar ve buna bağlı olarak ulaşım hizmetlerinin sağlanmasında görev, sorumluluk ve yetkileri vardır. Ancak Van Büyükşehir Belediyesi'nin imar işlerinin yanı sıra ulaşım ile ilgili sorumlulukları da yürüttüğü buna karşın bir ana ulaşım planının olmadığı görülmektedir. Bununla birlikte kentte ulaşımdan kaynaklı sorunların çözümünde daha çok toplu taşım ücret değişikliği tarifesi, hız kesici taleplerinin uygulanması, parkomat uygulaması, güzergâh değişimi gibi trafik iyileştirme politikaları kapsamında düzenleme ya da değişikliklerin uygulandığı görülmektedir (Ek 1 ve Ek 2). Bunların dışında kent merkezi 
iş alanı içinde 2017 yılında başlayıp 2018 yılında tamamlanmış Şemsiye Sokak gibi yayalaştırma çalışmaları da olumlu uygulamalardır.

Van Büyüksşehir Belediyesi, 76.803'e ulaşan 2016 yılı_ Mayıs Ayı Motorlu Kara Taşıtları verilerinden hareketle özellikle kent merkezindeki trafik yoğunluğuna çözüm olarak bazı düzenlemelerin yapılması gerekliliğini görmüştür. Buradan hareketle; Büyükşehir Belediyesi trafik akışının zaman zaman durma noktasına geldiği ana caddeler üzerinde trafik akışının düzenlenmesi amacı ile Ulaşım Koordinasyon Merkezi Kurulunca (UKOME) İpekyolu ilçesinin sekiz caddesi üzerindeki "Yol Kenarı Park" sisteminin uygulanmasına dair 29/12/2016 Tarih ve 92 sayılı Karar alınmış ve bu karar doğrultusunda 14.08.2017 tarihinde 922 araçlık alanda "parkomat" uygulaması fiili olarak başlamıştır. Parkomat, ilgili kamu kuruluşu tarafından araç park yeri olarak tahsis edilmiş ana cadde/ sokak üstü, yol kenarı, meydan, açık ve kapalı otopark alanlardaki işgal bedelinin tahsilâtını otomatik olarak yapan ve makbuzunu veren cihazdır. Park alanlarını kullanan araç sahiplerinin, kamu yararına kullanılması amaçlanan; belediye tarafından belirlenen tarife karşılığı yaptıkları ödemeleri tahsil ve kayıt edilmektedir. İlgili tarihten itibaren Van kent merkezinde bulunan Cumhuriyet Caddesi, Mareşal Fevzi Çakmak Caddesi, Sıhke Caddesi parkomat uygulamasının (yol kenarı park ücretlendirmesi) fiili olarak başladığı caddeler arasındadır (Bkz. Şekil 2b). 2019 yılında İki Nisan Caddesi, Milli Egemenlik Caddesi, İrfan Baştuğ Caddesi ve Uzun Sokak da parkomat uygulamasına dâhil edilerek 1570 araçlık alana çıkılması hedeflenmiştir. Ancak 18. 01. 2018 tarih ve 1 sayılı Karar ile Cemaller Sokak'da parkomat uygulaması dönüşlerde araç manevra kabiliyetine engel olduğu için kaldırılmıştır. 19.08.2018 tarih 92 sayılı Karar ile Kazım Karabekir Bulvarı parklanma sorunu olmadığı için parkomat uygulaması kapsamından çıkarılmıştır. Aynı karar ile İki Nisan Caddesi için alınan hem parkomat uygulaması hem de park yasağı fiili olarak hala (2019 yılı) başlamamıştır (Tablo 1).

Parkomat uygulama tarifesi 2018-2019 yıllarında geçerli olmak koşulu ile yaz aylarında 08.30 ile 20.00 saatleri arasında; kış aylarında ise 08.00 ile 18.00 saatlari arasında geçerlidir. Ücret tarifeleri ilk 10 dakikası ücretsiz olmak koşulu ile "0-15 dakika 1,50 TL, 0-30 dakika 2,00 TL, 0-45 dakika 3,00 TL, $0-60$ dakika 4,00 TL, 1-2 saat 5,00 TL, 2-3 saat 8,00 TL, 3-4 saat 10,00 
TL, 4-5 saat 15,00 TL, 5 saat ve üzeri otoparklar için ise 20,00 TL" biçiminde belirlenmiştir (Van Büyükşehir Belediyesi, 2019).

Tablo 1. Yol Kenarı Park Ücretlendirmesi (Parkomat) İçinde Kalan Caddeler

\begin{tabular}{|c|c|c|c|}
\hline Cadde Adı & Açıklama & $\begin{array}{l}\text { Araç } \\
\text { Kapasi- } \\
\text { tesi }\end{array}$ & $\begin{array}{l}\text { UKOME karar nu- } \\
\text { marası }\end{array}$ \\
\hline $\begin{array}{l}\text { Cumhuriyet } \\
\text { Caddesi }\end{array}$ & $\begin{array}{l}\text { Beşyol kavşağından İki Nisan kavşağına kadar yolun } \\
\text { her iki yönü(Otobüs durak yerleri ve kavşaklara giriş } \\
\text { ve çıkışlarında } 50 \mathrm{~m} \text { hariç) }\end{array}$ & 296 & $\begin{array}{l}\text { "29.12.2016 Tarih ve } \\
\text { 92 Sayılı Karar" }\end{array}$ \\
\hline $\begin{array}{l}\text { Mareşal Fevzi } \\
\text { Çakmak Cad- } \\
\text { desi }\end{array}$ & $\begin{array}{l}\text { Soydan Kavşağından Milli Egemenlik Cad.'ne kadar } \\
\text { her iki yönü(Otobüs durak yerleri ve kavşaklara giriş } \\
\text { ve çıkışlarında } 50 \mathrm{~m} \text { hariç) }\end{array}$ & 70 & $\begin{array}{l}\text { "29.12.2016 Tarih ve } \\
92 \text { Sayılı Karar" }\end{array}$ \\
\hline Sihke Caddesi & & & $\begin{array}{l}\text { "29.12.2016 Tarih ve } \\
92 \text { Sayılı Karar" }\end{array}$ \\
\hline İskele Caddesi & & & $\begin{array}{l}\text { "29.12.2016 Tarih ve } \\
92 \text { Sayılı Karar" }\end{array}$ \\
\hline $\begin{array}{l}\text { Ferit Melen } \\
\text { Bulvarı }\end{array}$ & & & $\begin{array}{l}\text { "29.12.2016 Tarih ve } \\
92 \text { Sayılı Karar" }\end{array}$ \\
\hline $\begin{array}{l}\text { Zübeyde Ha- } \\
\text { nım Caddesi }\end{array}$ & & & $\begin{array}{l}\text { "29.12.2016 Tarih ve } \\
92 \text { Sayılı Karar" }\end{array}$ \\
\hline Sihke Caddesi & & & $\begin{array}{l}\text { "29.12.2016 Tarih ve } \\
\text { 92 Sayılı Karar" }\end{array}$ \\
\hline $\begin{array}{l}\text { Cemaller So- } \\
\text { kak }\end{array}$ & $\begin{array}{l}\text { Sihke Caddesi'nden Koçibey Caddesi'ne kadar(Oto- } \\
\text { büs durak yerleri ve kavşaklara giriş ve çıkışlarında } \\
50 \mathrm{~m} \text { hariç) }\end{array}$ & 31 & $\begin{array}{l}\text { "18.01.2018 Tarih } 1 \\
\text { Sayılı Karar" }\end{array}$ \\
\hline $\begin{array}{l}\text { İfan Baştuğ } \\
\text { Caddesi }\end{array}$ & $\begin{array}{l}\text { Başlangıç noktası Endüstri Meslek Lisesi, bitiş nok- } \\
\text { tası Valilik Binası }\end{array}$ & 77 & $\begin{array}{l}\text { "19.08.2018 Tarih ve } \\
92 \text { Sayılı Karar" }\end{array}$ \\
\hline Uzun Sokak & $\begin{array}{l}\text { Başlangıç Aydın Perihanoğlu AVM, Bitiş noktası Ay- } \\
\text { nalı Kavşak }\end{array}$ & 236 & $\begin{array}{l}\text { "19.08.2018 Tarih ve } \\
92 \text { Sayılı Karar" }\end{array}$ \\
\hline $\begin{array}{l}\text { İkinisan Cad- } \\
\text { desi* }^{\text {lesi }}\end{array}$ & $\begin{array}{l}\text { Başlangıç noktası İkinsan Kavşağı, bitiş noktası İkini- } \\
\text { san-Erek Kavşağı }\end{array}$ & 265 & $\begin{array}{l}\text { "19.08.2018 Tarih ve } \\
92 \text { Sayılı Karar" }\end{array}$ \\
\hline $\begin{array}{l}\text { Kazım Karabe- } \\
\text { kir Caddesi }\end{array}$ & $\begin{array}{l}\text { Soydan Kavşağından Zübeyde Hanım Caddesi'ne } \\
\text { kadar(Otobüs durak yerleri ve kavşaklara giriş ve çı- } \\
\text { kışlarında } 50 \mathrm{~m} \text { hariç) }\end{array}$ & 67 & $\begin{array}{l}\text { "19.08.2018 Tarih ve } \\
\text { 92 Sayılı Karar" }\end{array}$ \\
\hline $\begin{array}{l}\text { Milli Egemen- } \\
\text { lik Caddesi }\end{array}$ & $\begin{array}{l}\text { Başlangıç noktası İkizler Lahmacun Fırını önü, bitiş } \\
\text { noktası Kültür Sarayı sonraki kavşağa kadar. }\end{array}$ & 140 & $\begin{array}{l}\text { "31.08.2018 Tarih ve } \\
69 \text { sayılı Karar" }\end{array}$ \\
\hline
\end{tabular}

*iki Nisan Caddesi; MİA uzantısı içinde kentin prestij caddesi olarak projelendirilmiştir.

Kaynak: Van Belediyesi,2019; “2016-2018 UKOME kararlarından” yararlanarak oluşturulmuştur.

Bu makalenin çıkış kaynağını oluşturan bir başka önemli düzenleme ise kent merkezindeki trafik yoğunluğuna çözüm gerekçesi ile yukarıda da bahsi geçen 29.12.2016 tarih 92 sayılı Karar itibari ile kent merkezindeki trafik akışının düzenlenmesi için; 02.03.2017 tarihli 1 sayılı Karar ile 422 
Adet Minibüsün (M plakalı) güzergâh değişikliği yapılmıştır. Ardından 14.09.2017 Tarihli 62 Karar Sayılı karar ile H tipi Halk Otobüslerinin güzergâhı ile ilgili değişikliğe gidilmiştir. Bu kapsamda kamu (belediye otobüsü) ve özel (minibüs ve halk otobüsü) olmak üzere kent merkezinde tüm toplu taşıma araçları için güzergâh değişikliğinin yapılması gerekli görmüştür.

Trafik akışının rahatlamasına/yoğunluğun önlenmesine yönelik 14.09.2017 Tarih ve 62 sayılı Karar bağlamında; Cumhuriyet Caddesi'nin Beşyol Kavşağı ile Mustafa Çohaz Kavşağı arasında kalan kısmı ve Ferit Melen Caddesi'nin bir kısmı toplu taşıma güzergâhından çıkarılmıştır (Şekil 8).

Değişiklik Öncesi

Güzergâh

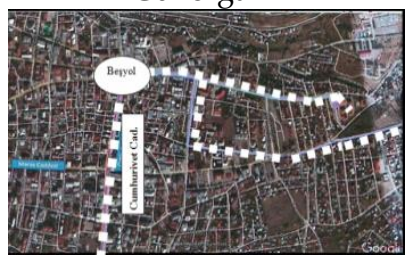

Değişiklik Sonrası Güzergâh
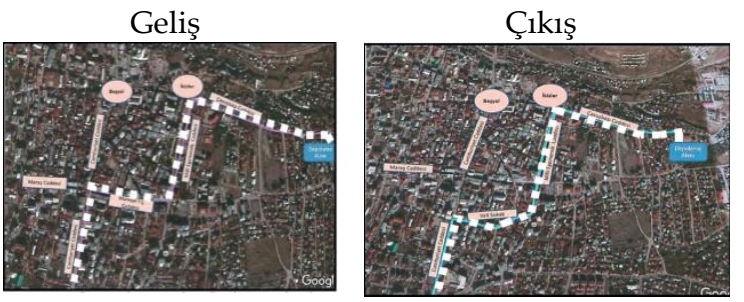

Şekil 8. Toplu taşıma değişiklik öncesi ve sonrası güzergâh ("14.09.2017 Tarih ve 62 sayılı Karar öncesi ve sonrasi)

İlgili yerel yönetim olarak Van Büyükşehir Belediyesi'nin 14.09.2017 tarih ve 62 sayılı Kararı öncesi kullanılan toplu taşıma güzergâhı Şekil 9'da daha detaylı bir şekilde görülmektedir.

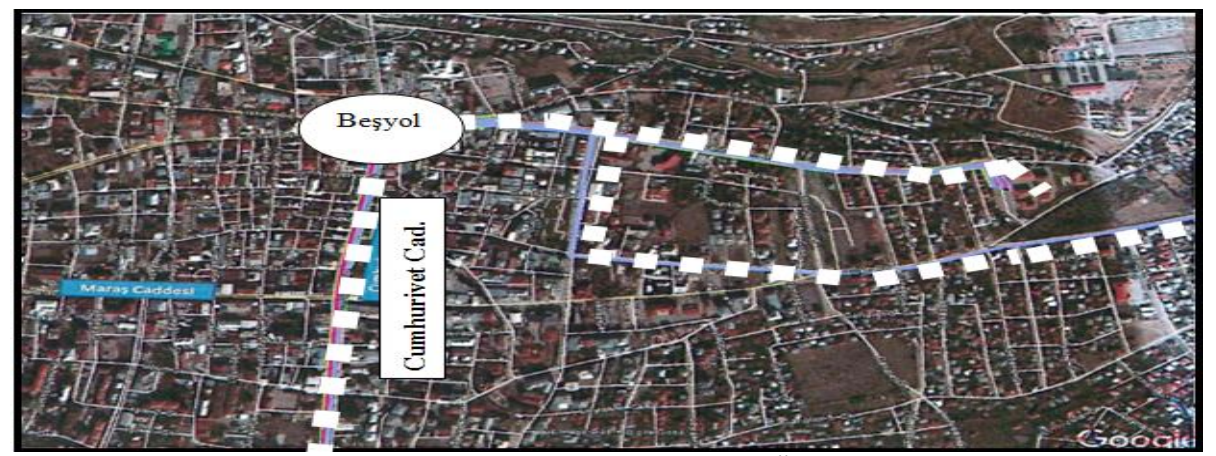

Şekil 9. 14.09.2017 Tarih ve 62 Sayılı UKOME Kurul Kararı "Öncesi" Toplu Taşıma Güzergâhı (Beyaz kesikli hat) 
Aşağıda 03.04.2018 tarihinde sabah 8.30-9.00 (işe gidiş) ve 17.30-18.00 (iş çıkışı) saatlerinde, yerinde çekilen fotoğraflar yer almaktadır. Bu güzergâh kent merkezinde; 14.09.2017 tarih ve 62 Sayılı UKOME Kurul Kararı'ndan önce kullanılan toplu taşıma güzergâhıdır. Değişiklik öncesi bu güzergâhta, Cumhuriyet Caddesi'nin Beşyol Kavşağı ile Mustafa Çohaz Kavşağı arası dâhildir (Şekil 9).

Yoğunluğun olabileceği sabah ve akşam üstü saatleri değerlendirildiğinde; bu güzergâhta Beşyol Ferit Melen Caddesi ve Cumhuriyet Caddesi'nin araç yoğunluğunun akşam saatlerinde arttığı görülmektedir.

\subsection{0-9.00 Saatleri Arasi}

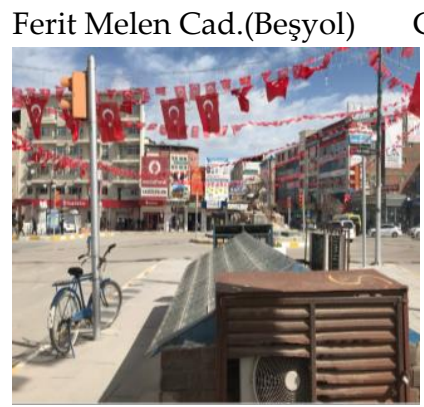

17.30-18.00 Saatlari Arasi

Ferit Melen Cad.(Beşyol)

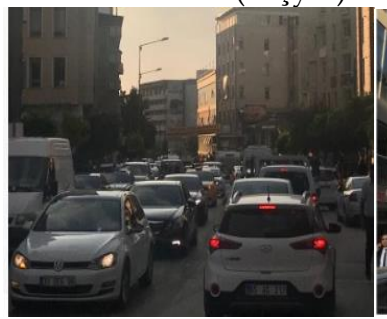

Cumhuriyet Caddesi

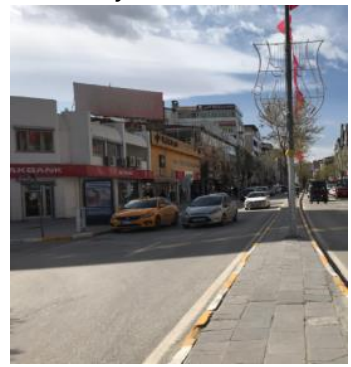

Ferit Melen Cad.(Beşyol)
Cumhuriyet Caddesi

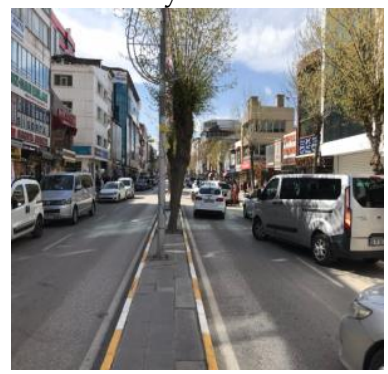

Cumhuriyet Caddesi
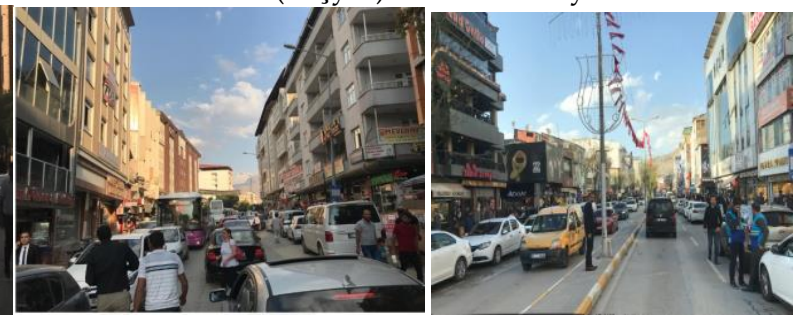

Şekil 10'da 14.09.2017 tarih ve 62 sayılı Kararı ile değiştirilen güzergâh görülmektedir. Şu anda bu güzergâhı kullanan toplu taşıma araçları Mustafa Çohaz Kavşağı'ndan doğu yönünde sağa dönerek Mareşal Fevzi Çakmak Caddesi'ne bağlanarak, Kültür Kavşağından kuzey yönünde sola dönerek, Mili Egemenlik Caddesi'ne bağlanarak, İkizler Kavşağına gelen araçlar doğu yönünde sağa dönerek Çavuşbaşı Caddesi üzeriden depolama sahasına intikal etmektedirler. 


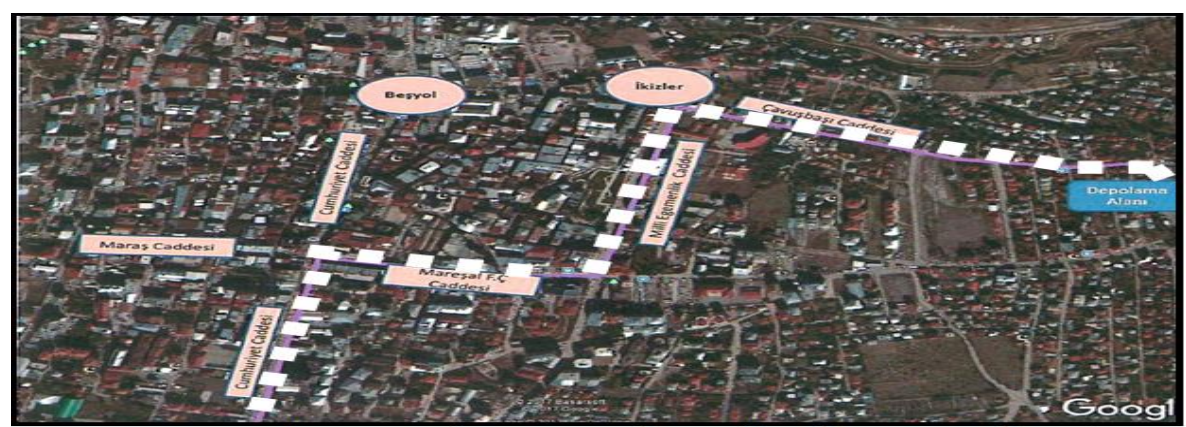

Şekil 10. 14.09.2017 Tarih ve 62 Sayılı UKOME Kurul Karan ile Toplu Taşıma Depolama Alanına Geliş Güzergâhları (Beyaz kesikli hat)- Şu anda güncel olan

Ayrıca çıkış/dönüş güzergâhı olarak Çavuşbaşı Caddesi, İkizler Kavşağı'ndan güney yönünde sola dönerek Milli Egemenlik Caddesi, Kültür Sarayı'nı geçtikten güney yönünde sağa dönerek Vali Sokak'a bağlanmakta ve Vali Sokak'ın sonunda güney yönünde sola dönerek mevcut güzergâhlarına devam etmektedirler (Şekil 11).

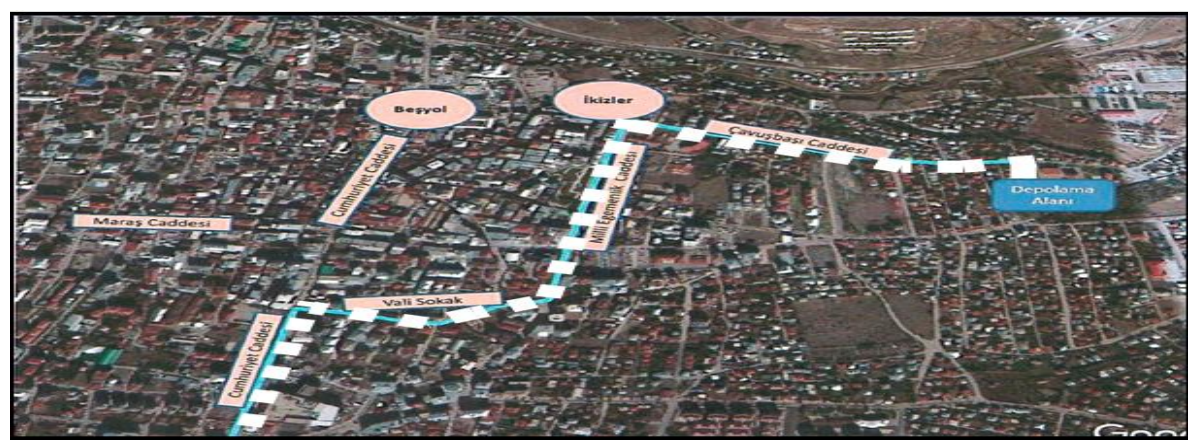

Şekil 11. 14.09.2017 Tarih ve 62 Sayılı UKOME Kurul Kararı ile Toplu Taşıma Depolama Alanından Çıkış Güzergâhı (Beyaz kesikli hat)- Şu anda güncel olan güzergâh

Aşağıda, 03.04.2018 tarihinde akşam üstü 17.30-18.00 saatlerinde (iş çıkışı) görülen yerinde çekilen fotoğraflar yer almaktadır. Bu güzergâh kent merkezinde; 14.09.2017 tarih ve 62 Sayılı UKOME Kurul Kararı sonrası kullanılan toplu taşıma güzergâhıdır. Değişiklik sonrası bu güzergâhta Cumhuriyet Caddesi'nin Beşyol Kavşağı ile Mustafa Çohaz Kavşağı arası dâhil 
değildir. Sadece Cumhuriyet Caddesi'nin Mustafa Çohaz Kavşağ ile Van AVM (alışveriş merkezi) kavşağı arası dâhildir (Şekil 10 ve Şekil 11).

Yoğunluğun olabileceği sabah ve akşam üstü saatleri değerlendirildiğinde; Cumhuriyet Caddesi'nin güzergâh içinde kalan kısmı ve Milli Egemenlik Caddesi'nde araç yoğunluğunun akşam saatlerinde arttığı görülmektedir.

\subsection{0-9.00 Saatleri Aras1}

İkizler Kavşağı- Milli Egemenlik Caddesi Arası

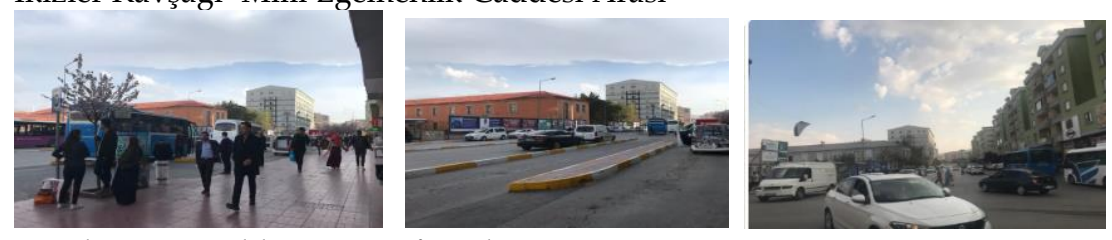

Cumhuriyet Caddesi (Mustafa Çohaz Kavşağı- Van Avm Kavşağı arası)
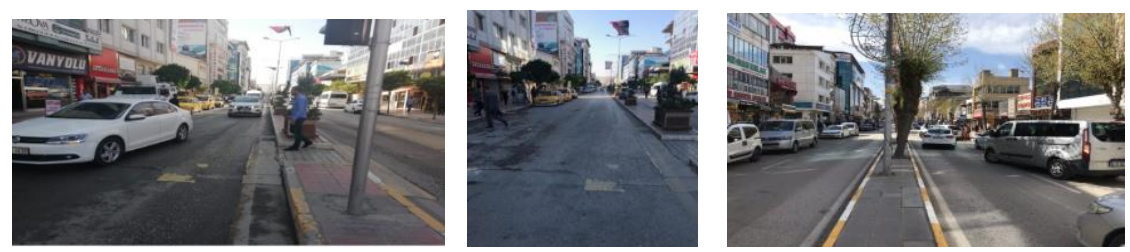

17.30-18.00 Saatlari Arası

İkizler Kavşağı- Milli Egemenlik Caddesi Arası
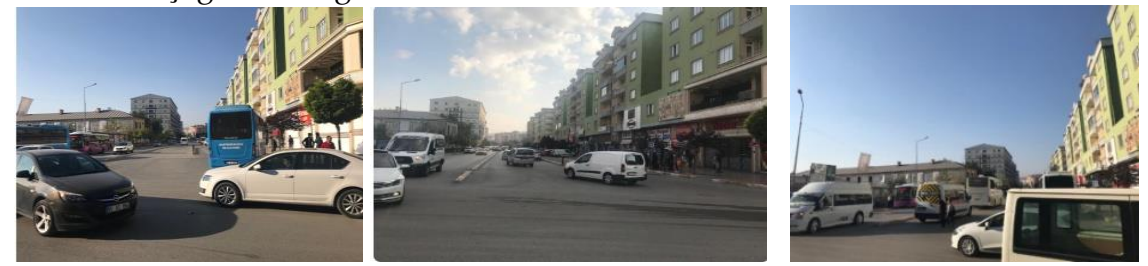

Cumhuriyet Caddesi (Mustafa Çohaz Kavşağı- Van Avm Kavşağı arası
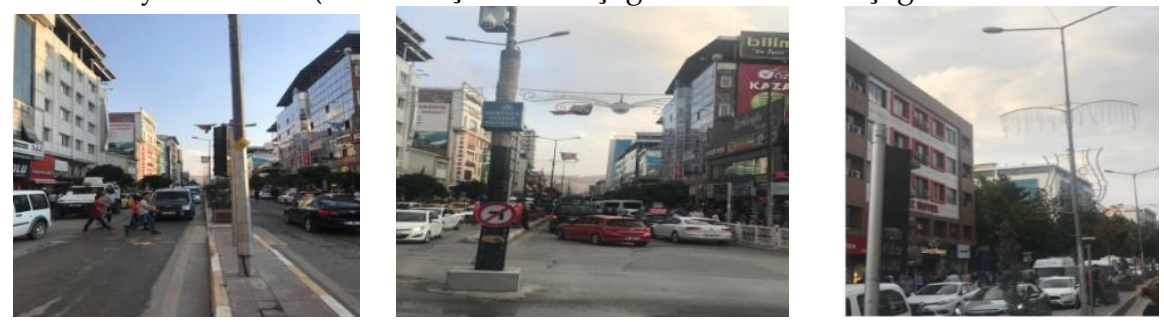
Yukarıda bahsi geçen gerek toplu taşıma araçlarının güzergâh değişimine gerek parkomat uygulamasına ilişkin kararların kentte bir ulaşım ana planı olmadan alındığı görülmektedir. Öte yandan söz konusu güzergâh değişimi ve hatta parkomat uygulaması trafik iyileştirme amaçlı kısa vadeli, geçici, noktasal politikalardır. Diğer taraftan ilgili yerel yönetimin yetkisi dâhilinde olsa da alınan kararların alt bir etüt çalışmasına dayanmadığı tespit edilmektedir. Ayrıca bu kararların alındığı süreçte yetkili yerel yönetim de, güzergâhların hafta içi ve hafta sonları hem pik (işe ve okula gidiş, iş ve okul çıkışı vb.) hem de günün farklı saatlerinde ne tür bir yoğunluk içinde olduğunu gösteren analitik bir trafik sayımı yapılmadığını, artan nüfusa ve özel araç sayısına yönelik farklı kararlar geliştirilmediğini, yolculuk üretim ve çekim analizlerinin yapılmadığını ve 14.09.2017 tarih ve 62 sayılı karar öncesi ve karar sonrası güzergâhların birbirlerine hangi açlardan alternatif olacağına ilişkin analitik bir çalışma yapılmadığını belirtmiştir. Diğer bir deyişle bu güzergâhların trafik sayımı, yolculuk yükü vb. açılardan birbirleri ile karşılaştırmasının yapılmadığı ve bu nedenle uygulamaya ilişkin alınan kararın/kararların analitik bir altlığa oturmadığı görülmektedir. Kent merkezinin 2019 yılında çekilen fotoğrafları yaya,bisiklet,toplu taşıma ve otomobil bağlamında kentin ulaşım sorunlarının çözümünde bağlayıcı ve bütüncül bir ulaşım ana planının gerekliliğini bir kez daha gözler önüne sermektedir.
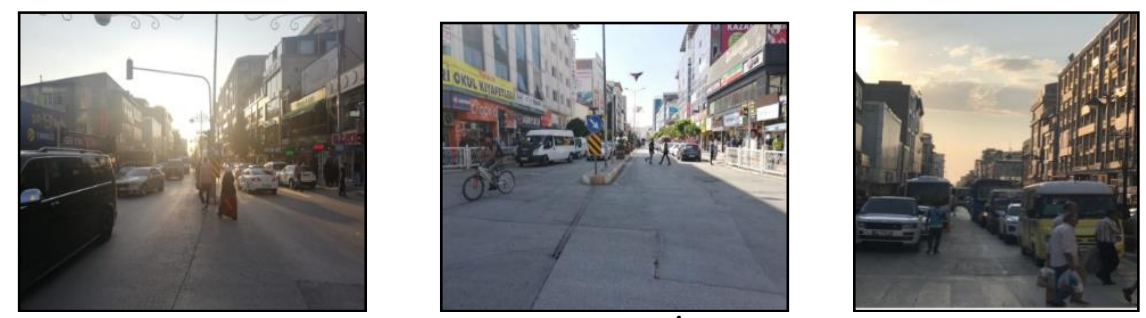

Şekil 12. 2019 yılı Van Kent Merkezi İş Alanından Görüntüler

\section{Sonuç Yerine}

Kentler, teknolojik gelişme, sanayileşme ve iktisadi faaliyetlerle birlikte nüfusun arttığı ve yoğunlaştığı alanlardır. Kentlerde nüfus artışı yeni yerleşim alanlarını doğurmaktadır. Yerleşim alanlarının birbirinden uzaklaşması ulaşım maliyetlerinin artmasına ve taşıma hizmetinin etkinliğinin 
azalmasına neden olmaktadır. Bu nedenle literatürde kompakt şehir formunun ulaşım hizmetleri açısından daha sürdürülebilir olduğu görüşü yaygındır. Ancak karşı görüş; bu yaklaşımın banliyö ve yarı-kırsal konut gelişimlerini reddettiği, bazı yaşam kalitesi özelliklerini karşılamadığını ileri sürmektedir. Bu nedenle kompakt kent formunun enerji verimliliği avantajlarını, yaşam kalitesi yönleriyle birleştirmek amacı ile kompakt şehir formuna çeşitli alternatifler geliştirilmiştir. $\mathrm{Bu}$, alternatifler şunlardır: köykent; yeni şehircilik; sürdürülebilir kentsel matris; transit odaklı gelişme, akıllı büyüme; ve desantirilize derişim(yoğunluk). Akıllı ulaşım sistemlerinin geleneksel toplu taşıma sistemlerine karşı daha çevre dostu bir alternatif olarak geleneksel toplu taşıma sistemleri ile entegre olarak kullanıldığında kentsel ulaşım sisteminde büyük avantajlar sağlayacağı ileri sürülmektedir (Yiğitcanlar, Fabian ve Coiacetto, 2008, s.30). Gelişmekte olan ülkelerin Van gibi kentlerinde sistematik bir kentsel ulaşım yapısı olmadığından henüz bu sistemleri tartışabilmek için erken olduğu söylenebilir.

Nijkamp (1999) ve Shiftan, Kaplan ve Hakert (2003) beş ana faktörün ulaşımın gelişimini etkilediğini belirtmektedir. Bunlar mekansal ve arazi kullanım düzenleri, hükümet politikası, ekonomik güçler, teknoloji ve sosyal ve davranışsal eğilimlerdir. Bu faktörlerin her biri zamanla gelişir ve hem birbirlerini hem de ulaşım sistemini etkiler (Yiğitcanlar, Fabian ve Coiacetto, 2008, s.29). Bu beş faktör kısaca aşağıda görüldüğü gibidir (Shiftan, Kaplan ve Hakert 2003; alıntılayan Yiğitcanlar, Fabian ve Coiacetto, 2008, s.29):

- Mekansal ve arazi kullanım deseni: Seyahate talep ve dolayısiyla ulaşım sistemi, kentsel alanın büyüklüğü, bina yoğunluğu, kenteki uzmanlaşma düzeyi ve kentsel alandaki faaliyetlerin yayılmasından etkilenmektedir. Binaların ve altyapının uzun ömürlü olmasından dolayı, mekansal kalıpların ulaştırma üzerindeki etkisi uzun vadelidir.

- Hükümet politikası: Yetkili makamlar, uzun vadeli planlama ihtiyacı, büyük finansal yatırım ve olumsuz dış etkilerin göz önünde bulundurulması gibi çeşitli nedenlerle ulaştırma gelişimine şiddetle katılmaktadır. Bu nedenle, ulaştırma gelişimi politik önceliklere duyarlıdır. 
- Ekonomik güçler: Büyük ölçekli ulaştırma projeleri, büyük finansal yatırımlar, ihtiyaç duyulan birincil sermaye, projelerin uzun süre ve düşük getiri oranı nedeniyle ekonomik değişikliklere karşı oldukça hassastır.

- Teknoloji: Teknoloji, atık arıtma işlemlerini iyileştirerek ve böylece kirliliği azaltarak ve aynı zamanda iletişim yoluyla fiziksel seyahatin yerine geçenleri sunarak sürdürülebilir taşımacılığa katkıda bulunabilir. Bununla birlikte, ulaşımdaki teknolojik gelişme, esasen projelerin ölçeği ve maliyeti, araştırma ve geliştirmenin uzun zaman çerçevesi ve altyapı ile mobil ekipmanın uzun ömürlü olması gibi nedenlerden dolayı nispeten yavaştır.

- Sosyal davranış ve eğilimler: Bireysel davranış, alışkanlıkların pratik ve duygusal düşüncelerin bir birleşimidir. $\mathrm{Bu}$, sosyal değerler ve normlar, bireyin ulaşım seçimini büyük ölçüde etkileyebilir.

Özellikle gelişmekte olan kentlerde yerel yönetimler; nüfusun büyümesi, finans eksikliği, kentsel altyapının yenilenememesi gibi sorunlara çözüm üretmede aceleci davranabilmektedirler. Oysa kentlerde artan nüfusu yönetmek ve beraberinde ekonomik büyümeyi sürdürmek için, kentsel ulaşım sistemlerinin sürdürülebilir olması sadece trafik akışının kolaylaştırılması değil, bir şehir/kent etrafında hareket etmenin birden fazla seçeneğin sunulması demektir (Tsay ve Herrmann, 2013, s.10).

Mekansal planlar ile uyumlu ve eş güdümlü ulaşım ana planı öncelikli olmakla birlikte; üç aşamalı bir strateji, sürdürülebilirliğin sağlanmasına yardımcı olabilir. Bu yaklaşımın ilk önceliği, özel araç kullanımı gibi karbon yoğun hareketlilik sistemlerinden kaçınmayı gerektirir. Toplu taşıma, yürüme ve bisiklete binme gibi çoklu sistemlere geçmek ikinci önceliği oluştururken, üçüncüsü mevcut altyapıyı, araç teknolojisini ve yakıtları geliştirmeyi içerir. Bu stratejik yaklaşım, ulaşımda hem arzı hem de talebi hedefleyerek performansı artırır. Şehirlerin mevcut altyapı üzerine inşa edilmesini sağlar ve yatırım yapılacak belirli bir teknolojiyi seçerken onlara daha fazla mobilite seçeneği sunar (Tsay ve Herrmann, 2013, s.10).

Bu çalışmada Van kent merkezi iş alanı odak olmakla birlikte Van kenti ele alınmaktadır. Van tek merkezli bir kent olup başlangıçta merkezin etrafında gelişim göstermiştir. 1990 yılı sonrası yoğun bir göç almış bu 
durum kent altyapısının da kaldıramayacağı fiziki, sosyal, ekonomik önemli değişimlere neden olmuştur. Diğer taraftan 2011 yılında ard arda yaşanan depremler sonrası kentin çeperlerinde yer seçen afet konut alanları; kentin makroformunun değişiminde etkili olmuş bir başka dinamiktir. Van 2013 yılından sonra büyükşehir statüsü kazanmıştır. Bu bağlamda 2011 yılında meydana gelen depremlere bağlı yeni yerleşim alanlarının oluşması ile kentin değişen makroformu, 2013 yılı itibari ile büyükşehir statüsü kazanması; fiziki, sosyal ve ekonomik ve aynı zamanda ilgili yasa ve yönetmelikler bağlamında bir ulaşım ana planını zorunlu kılmaktadır. Bu ulaşım ana planı hava, kara, demir ve deniz tüm ulaşım ağları ile birlikte düşünülmelidir. Ancak kentin hala bir ana ulaşım planı bulunmamakta ve henüz bu yönde bir çalışma da başlatılmamıştır.

Yerel yönetimlerin uzun vadeli hedeflerine ulaşabilmesi için aşağıdan yukarıya ve yukarından aşağıya bir yaklaşım gerekmektedir. Nijkamp (1999) ve Shiftan, Kaplan ve Hakert (2003) ve Tsay ve Herrmann'ın (2013) ifadelerinden hareketle Van kentinde de ilgili yerel yönetim/yönetimler; finans eksikliği, politik kaygılar, teknolojik yetersizlik ve bireylerin özel araç/otomobil kullanma eğilimi gibi nedenlerden ulaşım konusunda aceleci ve kaçınmacı bir yaklaşım içindedir. Ek 1 ve Ek 2' de görülen kent içi ve kent merkezindeki düzenlemeler ve uygulamalardan bu açıkca anlaşılmaktadır. Bu düzenlemeler, toplu taşım ücret değişikliği tarifesi, hız kesici taleplerinin uygulanması, parkomat uygulaması ve güzergâh değişimi gibi trafik akışını kolaylaştırma odaklı, daha çok kısa vadeli, noktasal ve ileriye dönük olmayan çözümlerdir. Çalışmanın çıkış noktasını oluşturan parkomat uygulaması ve toplu taşım güzergâh değişimi gibi kararlarında, temelde mevcut trafik yoğunluğu azaltma amacı taşıdığı görülmektedir. Bu anlamda kısmen kamu yararı taşıdığı söylenebilir. Ancak bu kararların ya da uygulamaların, avantaj ve dezavantajlarını ortaya koyan karşılaştırmalı analitik bir alt etüt(trafik sayımı, yolcu etüt, nüfus ve kullanım yoğunluğu vb.) çalışmasına dayanmadığı görülmektedir. İlaveten kent merkezinde; mümkün olduğunca bireysel araç/otomobil kullanımından uzaklaştıran, yaya ve entegre toplu ulaşım modlarını destekleyen değil daha çok üst gelir gurubunun eğilimi ve talebine göre şekillenen özel araç/otomobil odaklı bir yaklaşım içinde olunduğu görülmektedir. Diğer bir deyişle sosyal eşitlik, sosyal dişlanma ve yaşam kalitesi bağlamında kentin tüm kesimlerini (engelli, yaşlı çoçuk, kadın, 
genç ) gözeten, ilk iki bölümde ele alınan sürdürülebilir bir ulaşım politikası izlenebildiği söylenemez.

Özetle Van kent merkezinin ana güzergâhlarının yaya ve toplu taşıma öncelikli olarak yeniden gözden geçirilmesi, uzmanlarca bunlara ilişkin analitik etütlerin yapılması, özel araç kullanımını mümkün olduğunca minimize eden bir yaklaşım içinde olunması ve tüm bunların ötesinde acilen mekânsal planlar ile uyumlu kentin tümünü içeren bütüncül,sürdürülebilir ve uygulanabilir bir ana ulaşım planı hazırlığı içine girilmesi sorunların uzun vadece kalıcı olarak çözülmesi için önemlidir. Bu noktada kentsel ulaşımdan sorumlu ilgili yerel yönetimin/yönetimlerin, ilgili kamu kurum ve kuruluşları, sivil toplum kuruluşları ve kentli ile işbirliği içinde hareket etmesi finansal, fiziksel ve sosyal açından başarıya ulaşmalarında önemli bir adım olabilir. 
EXTENDED ABSTRACT

\title{
A Critical Perspective on Vehicle Car Oriented Regulations in Urban Transport
}

\author{
Aysu Uğurlar \\ Van Yüzüncü Yıl University
}

Since transportation is related to everyone's daily life, a sustainable urban transport service is one of the variables on which the quality of life is based. With the population increase in cities, the need for mobility increases, too. Since the 1970s, ownership of motor vehicles and private cars has also accelerated in cities. Conditions such as air and noise pollution, traffic congestions and accidents, consumption of finite resources indicate that motorized and private vehicle centered transport is no longer sustainable. In this context, sustainable transport is broadly defined as "meeting the need for mobility provided that it protects and improves human and ecosystem health, economic development, and social justice for the present and future". The concept of sustainable urban transport generally includes the increase in the number of motor vehicles, urban air pollution, road safety, transportation needs of lowincome groups, and transportation needs of the elderly, disabled, women, and children. Sustainable urban transport provides access to urban opportunities, minimizes social exclusion, and improves individuals' quality of life. It is important to define public transport and urban development strategies to create sustainable cities. In the context of sustainable urban transport, it is ideal to establish a comprehensive urban transport system that provides equal access to all members of the society, prioritizing public transport and non-motorized transport alternatives, and integrating with other types (modes) of transport. Today, sustainable urban transport is on the agenda of every developed and developing country and city. In developed countries, traffic reduction, limiting the use of private vehicles, increasing public transport, bicycle and pedestrian transportation are among the mainly adopted approaches. However, "urban transport" is critical in terms of sustainability in developing countries. It is observed in Turkey today that more than two-thirds of the population live in cities. Although the rate of urbanization has now decreased, the demographic change continues. Population density and the increase in the number of private vehicles in cities cause negative effects such as air and noise 
pollution, higher energy consumption and traffic congestions, especially in urban centers. The main source of the encountered problems is the adoption of private vehicle/automobile-oriented approaches rather than human/pedestrian-oriented ones in urban and transport planning. The social demand dimension of transportation needs to be addressed in a holistic way on the upper scale, not on an individual scale (multi-level roads, multi-level intersections, etc.). In the context of a holistic transport policy, the concept of "transportation master plan" has emerged from such a need.

In this study, the city of Van is discussed with a focus on the city center business area. Although the use of automobiles in Van ( 0.05 automobile per capita for 2018) seems to be low compared to the rest of the country in general, there is an increase in transportation problems such as traffic congestion and availability of parking lots etc. in the city, especially in the city center due to migration and population increase. Van is a single center city and initially developed around the center. After 1990, there was heavy migration that caused significant physical, social and economic changes that the city infrastructure could not handle. On the other hand, in the aftermath of the consecutive earthquakes in 2011, the disaster housing areas, whose locations were chosen at the perimeters of the city, have constituted another dynamic that has influenced the change of the city's macroform. Van gained a metropolitan municipality status after 2013. In this context, with the formation of new settlement areas due to the earthquakes in 2011, the city's changing macroform and its gaining metropolitan status as of 2013 necessitate a transportation master plan in the context of physical, social and economic requirements as well as relevant laws and regulations. However, the city still does not have a main transportation plan and no work has been initiated so far. From here, in this study, the processes of initiation of a parking meter system in Van city center and exclusion of a part of the Cumhuriyet Street, which is one of the important streets of the city center, from the public transportation route by the Van Metropolitan Municipality Transportation and Coordination Center (UKOME) in order to reduce the current traffic density are addressed in terms of legislation and spatial aspects and evaluated in the context of sustainable transportation policies. Local governments need bottom-up and top-down approaches to achieve their long-term goals. As Nijkamp (1999) and Shiftan, Kaplan and Hakert (2003), and Tsay and Herrmann (2013) point out, the relevant local administration/governments in Van also take a hasty and avoidant approach to transportation due to such reasons as lack of finance, political 
concerns, technological inadequacy and individuals' tendency to drive private vehicles/cars. This is evident from the arrangements and practices within the city and in the city center. These arrangements are mostly short-term, target a single point/issue and are non-forward looking solutions that focus on facilitating traffic flow such as change of public transport fare tariffs, fulfilment of speed cutter demands, parking meter and route changes. It is seen that decisions such as parking meter and public transport route change, which constitute the starting point of the study, are basically aimed at reducing the existing traffic density, too. In this sense, it can be said that it involves some public interest. However, it is seen that these decisions or practices are not based on a comparative analytical study (traffic census, passenger survey, population and usage intensity, etc.) which demonstrates the advantages and disadvantages. As a result, a re-review of the main routes of the Van city center with a priority on pedestrian and public transportation and implementation of related analytical studies by experts, adopting an approach that minimizes the use of private vehicles to the extent possible and, beyond all these, urgently preparing a holistic, sustainable and feasible main transportation plan that covers the whole city and is compatible with spatial plans are important for the long-term and permanent resolution of the problems. At this point, the relevant local authorities' responsible for urban transport acting in cooperation with relevant public institutions and organizations, non-governmental organizations and urban dwellers can be an important step towards success in financial, physical, and social terms.

\section{Kaynakça / References}

Acar, İ. H. (2003). Bütünleşik ulaşım politikası ve Avrupa kentsel şartı. Ulaşım ve dolaşım ilkeleri içinde (41-59), Ulaştırma Politikaları Kongresi, Türk Mühendis ve Mimar Odaları Birliği İnşaat Mühendisleri Odası, Ankara.

Akbulut, F. (2016). Kentsel ulaşım hizmetlerinin planlanması ve yönetiminde sürdürülebilir politika önerileri. Kastamonu Üniversitesi İktisadi ve İdari Bilimler Fakültesi Dergisi, 11(1), 336-355.

Akman G., Atakan A. (2016). İzmit kentiçi ulaşımda alternatif toplu taşıma sistemlerinin aksiyomlarla tasarım yöntemi ile değerlendirilmesi, Pamukkale Üniversitesi Mühendislik Bilim Dergisi, 22(1), 54-63.

Arpa,E. (2018). Van kent merkezi kullanıcılarının güvenlik algısı. Yüksek Lisans Tezi. Fen Bilimleri Enstitüsü, Van Yüzüncü Yıl Üniversitesi. 
Asımgil, B.(2017). Yayalaştırma - cadde tasarımları hareketi ve politikalarının oluşturulmasında halk katılımının sağlanması: Provo "beyaz bisiklet devrimi. Ege Mimarlik, 95(1), 34-39.

Balsas, C. J. (2015). Sustainable transportation planning, a new academic specialization in the USA. International Journal of Transportation Science and Technology, 4(1), 1-15.

Boltze, M., Tuan, V. A. (2016). Approaches to achieve sustainability in traffic management. Procedia engineering, 142, 205-212.

Boschmann, E. E., ve Kwan, M. P. (2008). Toward socially sustainable urban transportation: Progress and potentials. International journal of sustainable transportation, 2(3), 138-157.

Cirit, F. (2014). Sürdürülebilir kentiçi ulaşım politikalar ve toplu taşıma sistemlerinin karşılaştırılması. Uzmanlık Tezi. TC Kalkınma Bakanlığı, Ankara.

Gazete, R. (2004). 5216 Sayılı Büyükşehir Belediye Kanunu.

Gazete, R. (2005). 5393 Sayılı Belediye Kanunu.

Gazete, R. (2006). Büyükşehir Belediyeleri Koordinasyon Merkezleri Yönetmeliği.

Gazete, R. (2008). Ulaşımda Enerji Verimliliğinin Artırılmasına İlişkin Usul ve Esaslar Hakkında Yönetmelik.

Gazete, R. (2014). Mekânsal Planlar Yapım Yönetmeliği.

Google Map, (2019). Van. 12 Ocak 2019 tarihinde https://www.google.com.tr/maps adresinden erişildi.

Görentaş, G. (2015). Van'ın büyü̈şehir olma sürecinde ulaşım planlaması politika ve ilkeler. Yüksek Lisans Tezi, Bahçeşehir Üniversitesi, Fen Bilimleri Enstitüsü, İstanbul.

Neyastani, B. (2015). A Proposed Sustainable Transportation and Urban Mobility Design. MPRA-Munich Personal RePEc Archive, 1(1), 1-22.

Sutcliffe E. (2009 a). Sürdürülebilir ulaşım yaklaşımlarında dünya, Türkiye ve Ankara uygulamaları, 11(4), 37-46.

Sutcliffe E. (2009 b). Clean transport: Innovative solutions to the creation of a more sustainable urban transport system. Research in Transport and Logistics içinde ( 89-94), Dogus University Publication. İstanbul.

Şenbil, M. Fujiwara A. ve Zhang J. (2007). What can we do to decrease private car ownership and its usage in developing countries: A Capacity Development Approach for Jabotabek MA (Indonesia). Discussion Paper, 2007(2). 
Şeremet M., Alaeddinoğlu F. (2018). İletişim - etkileşim ve akışkan metanın coğrafyası: Ulaşım \& ulaştırma coğrafyası, Nurettin Özgen, Ed. Sosyal Coğrafya içinde, Ankara: Pegem Akademik Araştırmalar Yayınevi, , ss.203225, 201.

TBB(Belediyeler Birliği) (2016). Büyükşehir belediyeleri ulaşım koordinazyon merkezi (UKOME) kulavuzu. Ankara.

Tsay, S. P., ve Herrmann, V. (2013). Rethinking urban mobility: sustainable policies for the Century of the City. Washington, DC: Carnegie Endowment for International Peace.

TÜIK (2018). http://www.tuik.gov.tr

UNESCAP, CITYNET. (2011). Sustainable urban transportation systems. United Nations Economic and Social Commission.

Ürün U. (2015). Van kentinin deprem sonrası yeniden yapılandırılması sürecinde ulaşım sorunları ve geliştirilebilecek ulaşım politikaları. Yüksek Lisans Tezi, Bahçeşehir Üniversitesi, Fen Bilimleri Enstitüsü, İstanbul.

Van Büyükşehir Belediyesi (2019). 10 Ocak 2019 tarihinde https://van.bel.tr/HaberDetay/parkomata-2019da-da-zam-yok-.html adresinden erişildi.

Yiğitcanlar, T., Fabian, L. ve Coiacetto, E. (2008). Challenges to urban transport sustainability and smart transport in a tourist city: The Gold Coast, Australia. Open Transportation Journal, 2, 29-6. 


\section{Ekler}

\section{Ek 1. 2017 Y1lı UKOME Kararlar}

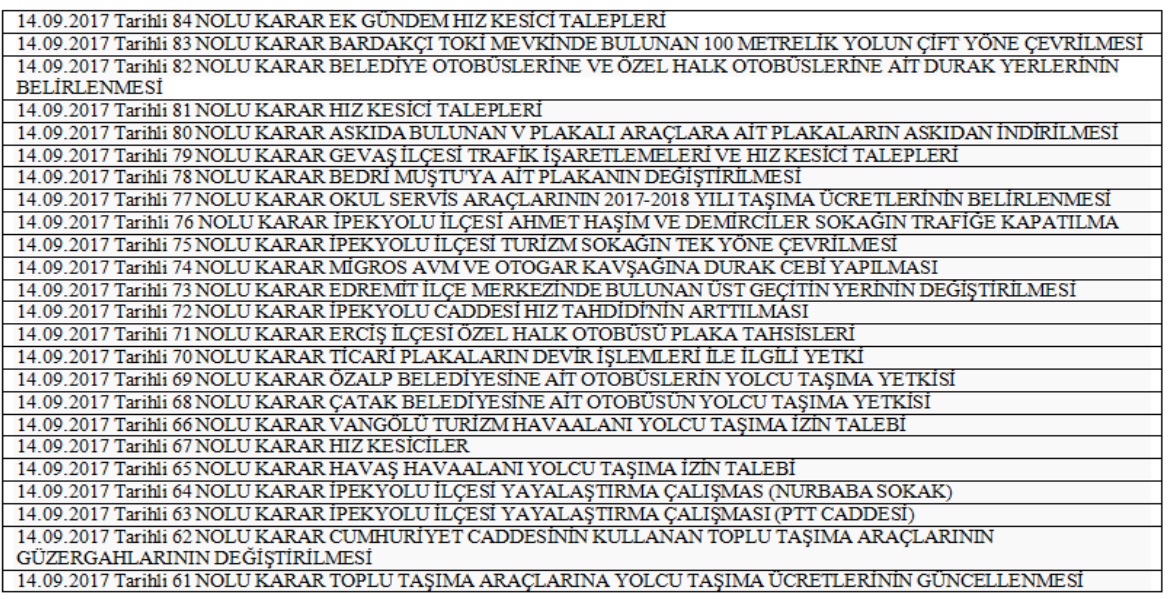

Kaynak: Van Belediyesi, 2019 https://van.bel.tr/ukome-kararlari.html

\section{Ek 2. 2018 Y1l UKOME Kararları}

\begin{tabular}{|c|}
\hline 13.09.2018 Tarihli YENI YOLCU TAŞIMA ÜCRETLERI \\
\hline 31.08.2018 Tarihli 64 NOLU KARAR 2018-2019 EǴITIM ÖG̈RETIM YILI OKUL SERVIS ARAÇLARI ÜCRET TARIFESİ \\
\hline 19.10.2018 Tarihli 96 NOLU KARAR GEMI YOLCU TAŞIMA ÜCRETLERININ GÜNCELLENMESI \\
\hline 19.10.2018 Tarihli 95 NOLU KARAR ASKIDA BULUNAN V PLAKARIN INDIRILMESI \\
\hline 19.10.2018 Tarihli 95 NOLU KARAR ASKIDA BULUNAN V PLAKARIN İNDİRILMESİ \\
\hline 19.10.2018 Tarihli 94 NOLU KARAR ÖZEL HALK OTOBÜSLERI AKTARMA SÜRESININ UZATILMASI \\
\hline $\begin{array}{l}\text { 19.10.2018 Tarihli 93 NOLU KARAR B2 ve D4 YETKI BELGESI ARAÇLARIN KUZEY ILÇE OTOGARINA } \\
\text { YONLENDIRILMESI }\end{array}$ \\
\hline 19.10.2018 Tarihli 92 NOLU KARAR PARKOMAT UYGULANACAKIAR CADDELERINN GÜNCELLENMESI \\
\hline 19.10.2018 Tarihli 91 NOLU KARAR TUŞBA İLÇESİ 15 TEMMUZ ŞEHITLER PARKI OTOPARKI \\
\hline $\begin{array}{l}\text { 19.10.2018 Tarihli 90 NOLU KARAR IPEKYOLU İÇESI ASKERLIK ŞUBESİ BİNASI ÖNÜNDE PARK YASAĞI } \\
\text { UYGULANMASI }\end{array}$ \\
\hline 19.10.2018 Tarihli 89 NOLU KARAR HIZ KESICILER \\
\hline 19.10.2018 Tarihli S8 NOLU KARAR YEDIEMIN OTOPARK VE ÇEKICI ÜCRETLERINIIN GÜNCELLEMESİ \\
\hline 19.10.2018 Tarihli 87 NOLU KARAR BOSTANIÇI MAHALLESI GÜZERGAH ÇALIŞMASI \\
\hline 19.10.2018 Tarihli S6 NOLU KARAR IPEKYOLU CADDESI SERVIS YOLLARININ ÇIFT YÖNLÜ TRAFIG̈E AÇILMASI \\
\hline 19.10.2018 Tarihli 85 NOLU KARAR HIZ KESICI TALEPLERI \\
\hline 19.10.2018 Tarihli 84 NOLU KARAR ASKIDA BULUNAN V PLAKALARIN INDIRILMESİ \\
\hline 19.10.2018 Tarihli 83 NOLU KARAR İKINISAN CADDESINDE PARK YASAǴININ UYGULANMASI \\
\hline $\begin{array}{l}\text { 19.10.2018 Tarihli } 82 \text { NOLU KARAR MURADIYE ILÇESI YENIŞEHIR MAHALLESI KA YMAKAMIIK BINASININ ONUNUN } \\
\text { KAPATILMASI }\end{array}$ \\
\hline 19.10.2018 Tarihli 81 NOLU KARAR MURADIYE IILÇESI ŞEYTAN KÖPRÜSÜNÜN TAŞIT TRAFIG̈INE KAPATILMASI \\
\hline 19.10.2018 Tarihli 80 NOLU KARAR ASKIDA BULUNAN TICARİ TAKSILERIN İNDIRILMESI \\
\hline 19.10.2018 Tarihli 79 NOLU KARAR 65 M 0096 NOLU PLAKANIN IPTAL EDILMESİ YERINNE 65 M 0269 VERILMESI \\
\hline 19.10.2018 Tarihli 78 NOLU KARAR ÇALDIRAN JANDARMA KOMUTANLIĠI ÖNÜNDE HEMZEMIN GEÇIT AÇILMASI \\
\hline
\end{tabular}


19.10.2018 Tarihli 78 NOLUKARAR ÇALDIRAN JANDARMA KOMUTANLIGI ONUNDE HEMZEMIN GEÇIT AÇILMASI

19.10.2018 Tarihli 77 NOLUKARAR IPEKYOLU IL ÇESI YUZBAŞIOGLU 1. SOKAGINTEK ŞERITE DUŞURULMESI

19.10.2018 Tarihli 76 NOLUKARAR GURPINAR IL ÇESI CUMHURIYET CADDESINDE BULUNAN BARIYERLERIN

KALDIRILMASI

19.10.2018 Tarihli 75 NOLUKARAR IPEK YOLUIL ÇESITIMURPAŞA VE MENEKŞE SOKAKT A BULUNAN BARIYERLERIN

KALDIRILMASI

19.10.2018 Tarihli 74 NOLUKARAR TAKSIMETRE FIYATLARININ GUNCELLENMESI

19.10 .2018 Tarihli 73 NOLUKARAR ERCIŞIL ÇESI OZEL HALK OTOBUSLERI YOLCU TAŞIMA UCRETLERININ

GÜNCELLENMESI

13.09.2018 Tarihli 70 NOLUKARAR YENI YOLCU TAŞMA UCRETLERI

31.08.2018 Tarihli 69 NOLUKARARMILLIEGEMENLIK CADDESI VE ESKI CEZAEVISOKAGA PARKOMAT

UYGULANMASI TALEBI

31.08.2018 Tarihli 68 NOLUKARAR HIZ KESICI TALEPLERI

31.08.2018 Tarihli 66 NOLUKARAR IPEKYOLU ILÇESIORDU CADDESINE TOPTANCI ARACCLARININ GIRMESININ

KISITLANMASI

31.08.2018 Tarihli 63 NOLUKARAR 2018 YILI YOLCU TAŞMMA UCRET TARIFEL ERI

13.07.2018 Tarihli 62 NOLUKARAR 15 TEMMUZ ŞEHITLER PARKI OTOPARKI

13.07.2018 Tarihli 61 NOLUKARAR ASKERLIK ŞUBESIBAŞKANLIGI ONUNUN TRAFIGE KAPATILMASI

13.07.2018 Tarihli 60 NOLUKARAR NAKLIYE ARAÇLARININ DEPOLAMAALANLARININ BELIRLENMESI

13.07.2018 Tarihli 59|NOLUKARAR S.S.3 NOLU S.S. 27 NOLU S.S. 36 NOLU S.S 86 NOLU KOOP. YOLCU INDIR BINDIR

13.07.2018 Tarihli 58 NOLUKARAR HIZ KESICILER

18.01.2018 Tarihli 17 NOLUKARAR TUŞBA IL ÇESI KOÇ ILKOGRETIM OKULU ONUNE UST GEÇIT YAPILMASI

18.01.2018 Tarihli 16 NOLUKARAR IPEKYOLU IL ÇESIERCIŞLI EMRAK SOKAGINTRAFIGE KAPATILMASI

18.01.2018 Tarihli 2 NOLU KARAR BELEDIYEOTOBUSL ERINE YENI EKILNEN GUZERGAHLARINUCRETLERI VE

DREMIT TOKI V PLAKA ÜCRETLERI

18.01.2018 Tarihli 1 NOLU KARAR PARKOMAT GUZERGAHI,ARDINDEGISৃTIRILMESI

Kaynak: Van Belediyesi, 2019 https://van.bel.tr/ukome-kararlari.html

\section{Kaynakça Bilgisi / Citation Information}

Uğurlar, A. (2019). Kentsel ulaşımda özel araç odaklı düzenlemelere eleştirel bir bakış. OPUS-Uluslararası Toplum Araştırmaları Dergisi, 13(19), 1976-2014. DOI: 10.26466/opus.607571 